\title{
Molten chloride salts for next generation concentrated solar power plants: Mitigation strategies against corrosion of structural materials
}

\author{
Wenjin Ding ${ }^{a, 1^{*}}$, Hao Shi ${ }^{b, 1^{*}}$, Adrian Jianu ${ }^{b}$, Yanlei Xiu ${ }^{a}$, Alexander Bonk ${ }^{a}$, Alfons \\ Weisenburger ${ }^{b}$, Thomas Bauer ${ }^{c}$ \\ anstitute of Engineering Thermodynamics, German Aerospace Center (DLR), Stuttgart, Germany \\ ${ }^{b}$ Institute for Pulsed Power and Microwave Technology, Karlsruhe Institute of Technology (KIT), \\ Eggenstein-Leopoldshafen, Germany \\ ${ }^{c}$ Institute of Engineering Thermodynamics, German Aerospace Center (DLR), Cologne, Germany \\ 1: co-first author. W. Ding and $\mathrm{H}$. Shi contributed equally to this work. \\ ${ }^{*}$ Corresponding author. Tel.: +49 22036013162. \\ E-mail address: wenjin.ding@dlr.de (W. Ding); hao.shi@partner.kit.edu (H. Shi)
}

\begin{abstract}
Molten chloride salts are promising advanced high-temperature $\left(400-800^{\circ} \mathrm{C}\right)$ thermal energy storage (TES) and heat transfer fluid (HTF) materials in next generation concentrated solar power (CSP) plants for higher energy conversion efficiencies. However, severe corrosion of structural materials in contact with molten chloride salts is one of the most critical challenges limiting their applications at elevated temperatures. In this work, two corrosion mitigation strategies are investigated to alleviate the hot corrosion of structural materials in molten chloride salts: (1) adding corrosion inhibitor and (2) using a FeCr-Al alloy with a protective alumina layer on the surface after pre-oxidation. Three commercial high temperature Fe-Cr-Ni alloys (SS 310, Incoloy ${ }^{\circledR} 800 \mathrm{H}$ and Hastelloy ${ }^{\circledR} \mathrm{C}-276$ ) were exposed to molten $\mathrm{MgCl}_{2}-\mathrm{NaCl}-\mathrm{KCl}$ (60-20-20 mole.-\%) mixed salts with $1 \mathrm{wt} . \% \mathrm{Mg}$ as corrosion inhibitor, for $500 \mathrm{~h}$ at $700^{\circ} \mathrm{C}$ under inert atmosphere. By addition of the $\mathrm{Mg}$ inhibitor, the corrosion rates of the studied alloys were found to be significantly reduced, more precisely by $\sim 3 \%$ for SS 310, 70\% for In $800 \mathrm{H}$ and $\sim 94 \%$ for Ha C-276 compared with the exposure tests without Mg addition. To assess the second mitigation strategy two pre-oxidized alumina forming Fe-Cr-Al alloys were exposed to the same molten chloride salts without $\mathrm{Mg}$ corrosion inhibitor under the same conditions. It is observed that the adherent alumina scales can effectively inhibit the dissolution of $\mathrm{Cr}$ and $\mathrm{Fe}$ and the bulk penetration of corrosive impurities. Overall, both strategies offer enormous potential for enhancing the expected lifetime of commercial alloys in molten chloride salts.
\end{abstract}

\section{Highlights}

- By Mg-addition the corrosion rates of alloy SS 310 , In $800 \mathrm{H}$ and Ha C-276 are significantly reduced. 
- Adding Mg inhibitor not only mitigates the corrosion caused by impurities, but also promotes the formation of protective $\mathrm{MgO}$ layer on metal surfaces.

- The corrosion mitigation mechanism of Fe-Cr-Ni based alloys in molten chloride salts by adding $\mathrm{Mg}$ is discussed.

- Pre-oxidized alumina forming Fe-Cr-Al alloys show promising corrosion resistance and stability in molten chloride salts at $700^{\circ} \mathrm{C}$ for $500 \mathrm{~h}$ exposure.

\section{Keywords}

Concentrated solar power (CSP), Thermal energy storage (TES), Molten salts, Corrosion mitigation, Corrosion inhibitor, Alumina forming Fe-Cr-Al alloys.

\section{Introduction}

Molten salts become increasingly attractive as thermal energy storage (TES) or heat transfer fluid (HTF) materials due to their expected thermal stability at high temperatures $\left(>600^{\circ} \mathrm{C}\right)$ and low costs [1-4]. Their energy related applications in e.g., advanced concentrated solar power (CSP) plants and advanced nuclear power plants have been widely reported [5-11]. Fig. 1 schematics a state-of-the-art CSP plant, in which the molten salts are used as low-cost HTF and large-scale TES materials. The key advantages of using molten salts as HTF and TES are their moderately low-costs, scalable energy storage capacity, low vapor pressure (unpressurized storage) and low viscosity (pumpability) [1-4]. Dispatchability in particular, makes CSP one of the most promising renewable energy technologies [2-5] in which nitrate salts are currently employed as TES and HTF materials [4,12-13]. Nitrate salts however, are limited to operating temperatures below $565^{\circ} \mathrm{C}$ due to thermal decomposition reactions and corrosion constraints [14-15]. Consequently, there is an urge to identify advanced HTF/TES materials with high temperature thermal stability and low costs, which will help improve the energy conversion efficiency and reduce the energy costs $[1,4]$.

Chloride salts are promising HTF/TES materials due to their low prices and wide operating temperature ranges [14,16-18]. Over the course of the SunShot Initiative, the U.S. Department of Energy (DOE) has supported the development of molten chloride salts for next generation CSP plants (Gen-3 CSP) [19]. Increasing the operation temperatures allows for higher conversion efficiencies of the power block. Furthermore, a larger temperature difference in the TES system reduces its capital costs. These benefits can result in reduced levelized costs of electricity (LCOE) [19]. Highly abundant chloride salts (e.g. $\mathrm{NaCl}, \mathrm{KCl}$ ) usually have a melting 
point above $750^{\circ} \mathrm{C}$ and boiling point above $1400^{\circ} \mathrm{C}[4,12]$. By addition of covalent metal halides like $\mathrm{MgCl}_{2}$ or $\mathrm{ZnCl}_{2}$, a eutectic mixed salt with low melting point $\left(<400^{\circ} \mathrm{C}\right)$ and high boiling point $\left(>800^{\circ} \mathrm{C}\right)$ is formed $[16,18,20]$. The chloride salts employed in this research are the mixed salts of $\mathrm{MgCl}_{2}, \mathrm{KCl}$ and $\mathrm{NaCl}\left(\mathrm{MgCl}_{2}-\mathrm{KCl}-\mathrm{NaCl}, 60-20-20\right.$ mole \%). This mixture has a low melting point $\left(<400^{\circ} \mathrm{C}\right)$, low price $(<0.5 \$ / \mathrm{kg})$ and high thermal stability $\left(>800^{\circ} \mathrm{C}\right)$ [21-22].

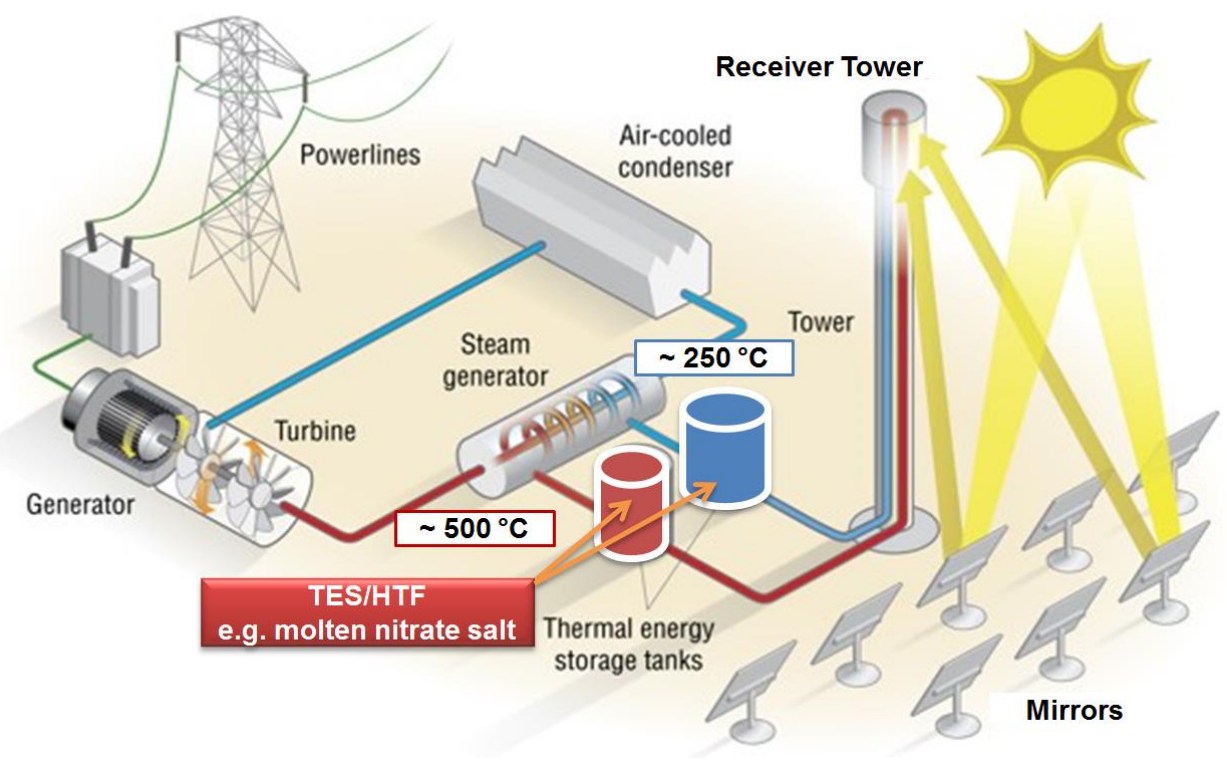

Fig. 1 Concentrated solar power plants with molten salts as TES and HTF materials

(source: US Department of Energy Report: The Year of Concentrating Solar Power, DOE/EE-1101, May 2014).

However, the compatibility issues especially the severe corrosion of structural materials make chloride salts challenging for high temperature applications [1,12,21]. Corrosion in molten chloride salts is different from that in molten nitrates and carbonates, in that alloys will not form a passive oxide scale to inhibit the corrosion during exposure due to oxide dissolution in the melt $[9,20]$. Generally, the corrosion of metals in molten chloride salts can be in the forms of electrochemical corrosion, impurities-driven corrosion, galvanic corrosion and temperature effects $[12,18,20,23]$. The more negative the reduction potential of the alloying element in chloride salts, the easier it will be corroded [20-23]. Therefore, it was observed that $\mathrm{Cr}$ was prone to be corroded, followed by $\mathrm{Fe}$, and $\mathrm{Ni}$ was noble [9,20-21]. Residual water from the added metal chlorides (covalent chlorides like $\mathrm{MgCl}_{2}$ are usually strongly hygroscopic) and increasing TES/HTF operation temperatures of CSP plants will accelerate the corrosion of structural materials, e.g., Fe-Cr-Ni based alloys [9,23-30]. The detrimental effects of residual moisture and oxygen in chloride salts and the atmosphere on the corrosion in molten chlorides have been reported by many researchers [9, 20-21, 23-30]. Vignarooban et al. (2015) [29] 
indicated that the corrosion rate of Hastelloy C-276 was only $10 \mu \mathrm{m} /$ year in $\mathrm{ZnCl}_{2}-\mathrm{NaCl}-\mathrm{KCl}$ in the absence of air at $800^{\circ} \mathrm{C}$, while it reached $80 \mu \mathrm{m} / \mathrm{year}$ even at $500^{\circ} \mathrm{C}$ in presence of air. Gomez-Vidal et al. (2016) [25] studied the corrosion behavior of Fe-Cr-Ni based alloys in molten $\mathrm{NaCl}$-LiCl salts under nitrogen atmosphere. Inconel 625 with a high $\mathrm{Ni}$ content showed the best corrosion resistance at $650^{\circ} \mathrm{C}$. But its high corrosion rate $(2800 \pm 0.38 \mu \mathrm{m} /$ year $)$ caused by the impurities in the salts is not acceptable for commercial applications [25]. Besides, increasing the temperature on one hand improves the energy conversion efficiencies of CSP plants, on the other hand, aggravates the corrosion process. Gomez-Vital et.al [25] indicated that an increase of temperature from $650^{\circ} \mathrm{C}$ to $700^{\circ} \mathrm{C}$ doubled the corrosion rate of SS 310 and Incoloy $800 \mathrm{H}$. EDX analysis of corroded samples showed the preferential dissolution of $\mathrm{Cr}$ and $\mathrm{Fe}$ in molten salt using these Fe-Cr-Ni based alloys [25].

Since molten chloride salts were considered as HTF candidates in nuclear power plants, some strategies have been developed to mitigate the corrosion of structural materials in contact with molten chloride salts $[9,20,31]$. Water vapor (moisture) and oxygen contaminants have been observed to react with the chlorine anion to produce $\mathrm{HCl}$ and $\mathrm{Cl}_{2}$, thereby increasing the corrosion rates $[18,20,32]$. Exposure of the samples to salts containing $\mathrm{MgCl}_{2}$ under inert atmosphere has been proven to significantly reduce corrosion effects [29]. Moreover, salt purification technologies could significantly reduce the level of corrosive impurities in the salts, especially for chloride salts, and thus the corrosion rates of structural materials in contact with the molten salts $[9,31]$. For example, the chloride salts are purified by $\mathrm{CCl}_{4}$ bubbling $(12 \mathrm{~h}$ at $550^{\circ} \mathrm{C}$ ) to remove the impurities containing oxygen and hydrogen [9].

Adding the corrosion inhibitor is an effective method to further mitigate the corrosion by lower the redox potential of the salts $[23,33]$. These inhibitors preferentially react with the corrosive impurities and consume them. Inhibitors used in different aggressive environments have been reported, for instance by adding Li metal in molten $\mathrm{LiCl}$ [34-35] or $\mathrm{Mg}$ in molten $\mathrm{MgCl}_{2}-\mathrm{KCl}$ [36], treating the FLiNaK salts with $\mathrm{Zr}, \mathrm{Be}$ or $\mathrm{Li}[20,37]$ and adding corrosion inhibitors for steels in acidic media [38]. The results of adding $\mathrm{Mg}$ metal in molten $\mathrm{MgCl}_{2}-\mathrm{KCl}$ [36] showed that the corrosion rate of the Ni-based Cr-Fe-Ni Hastelloy 230 in $\mathrm{MgCl}_{2}-\mathrm{KCl}$ with $1.15 \mathrm{~mol}-\% \mathrm{Mg}$ under inert atmosphere at $850^{\circ} \mathrm{C}$ was 35 times lower than baseline tests without $\mathrm{Mg}$, and the reduced corrosion rate of this alloy met the requirement for industrial applications ( $C R<15 \mu \mathrm{m} / \mathrm{year}$ ). However, this corrosion mitigation method and mechanism are still not investigated systemically 
for the promising $\mathrm{MgCl}_{2}-\mathrm{NaCl}-\mathrm{KCl}$ salts mixtures at relevant temperatures specifically for the CSP application.

Alloy modification is another approach to improve the corrosion resistance of the structural materials by creating a barrier that can avoid the direct contact of the alloys with corrosive media [39-40]. The barrier should be thermodynamically stable and corrosion resistant towards the aggressive environments, and a strong adherence to the bulk material is required. One kind of these promising barriers is an in-situ grown oxide scale, preliminarily formed during a high temperature oxidation step [40]. These scales generally consist of $\mathrm{Cr}_{2} \mathrm{O}_{3}, \mathrm{Fe}_{2} \mathrm{O}_{3}, \mathrm{Al}_{2} \mathrm{O}_{3}$ or their mixtures [32,39-40]. It is reported that $\mathrm{Cr}_{2} \mathrm{O}_{3}$ has a high dissolution rate in molten chloride salts, while $\mathrm{Al}_{2} \mathrm{O}_{3}$ is considered corrosion resistant [41-43]. Li et al. (2005) [41] studied the corrosion behavior of $\mathrm{Fe}-35 \mathrm{Cr}$ alloy in molten $\mathrm{NaCl}-\mathrm{KCl}$ salt mixtures in air. After $48 \mathrm{~h}$ exposure at $670^{\circ} \mathrm{C}$, only $\mathrm{Fe}_{2} \mathrm{O}_{3}$ remained while $\mathrm{Cr}_{2} \mathrm{O}_{3}$ was totally converted into chromates. Li et al. (2007) [42] showed that the degradation of Cr-forming alloys was caused by the formation of potassium chromate from $\mathrm{Cr}_{2} \mathrm{O}_{3}$ due to $\mathrm{KCl}$. It was also shown that a protective alumina layer, formed on Fe-20Al alloy by pre-oxidation, was stable during exposure to the molten $\mathrm{NaCl}-\mathrm{KCl}$ salt at $670^{\circ} \mathrm{C}$ for 48h under air atmosphere [42]. Vidal et al. (2017) [44] investigated the corrosion resistance of pre-oxidized alumina-forming alloys against molten $\mathrm{MgCl}_{2}-\mathrm{KCl}$ (35.59-64.41 wt.-\%) mixtures. Their results demonstrated the positive role of an $\mathrm{Al}_{2} \mathrm{O}_{3}$ scale in inhibiting the corrosion attack from chloride salts. Additionally, the high temperature mechanical properties of the aluminaforming alloys like strength and creep resistance can also be significantly improved by precipitation of secondary phases $\left(\mathrm{NbC}, \mathrm{Cr}_{23} \mathrm{C}_{6}, \mathrm{~B} 2[\mathrm{~b}-(\mathrm{Ni}, \mathrm{Fe}) \mathrm{Al}]\right.$, and Laves $\left[\mathrm{Fe}_{2}(\mathrm{Mo}, \mathrm{Nb})\right]$ ) [40,45-46]. Such kinds of alloys including the alumina-forming austenitic (AFA) steels and ferritic Kanthal alloys have been successfully developed for high-temperature thermal applications $[40,47]$. Besides, these alloys with a high Al content can be considered not only as structural materials but also as coating materials [48-49].

In this work, two corrosion mitigation strategies: (1) the addition of active metal Mg metal (2-5 $\$ / \mathrm{kg}$ ) as corrosion inhibitor and (2) the formation of a protective oxide scale on alumina-forming alloys are investigated to mitigate the hot corrosion in the molten chloride salts. Three commercial high temperature alloys with different $\mathrm{Ni}$ and $\mathrm{Cr}$ contents (SS 310, In $800 \mathrm{H}$ and Ha C-276) are selected and exposed to the molten chloride salts $\left(\mathrm{MgCl}_{2}-\mathrm{NaCl}-\mathrm{KCl} 60-20-20\right.$ mole \%) with 1 wt.-\% $\mathrm{Mg}$ addition for $500 \mathrm{~h}$ at $700^{\circ} \mathrm{C}$ under argon atmosphere. Another two alumina-forming Fe-Cr-Al alloys are pre-oxidized at $800^{\circ} \mathrm{C}$ in air and exposed to the molten 
chloride salts without $\mathrm{Mg}$ corrosion inhibitor for $500 \mathrm{~h}$ at $700^{\circ} \mathrm{C}$ under argon atmosphere. In order to guarantee the formation of a highly protective alumina oxide scale, $8 \mathrm{wt} . \% \mathrm{Al}$ is added in the Fe-Cr-Al alloys.

\section{Materials and methods}

\subsection{Materials}

$\mathrm{KCl}$ and $\mathrm{NaCl}$ with a purity $>99$ wt.-\% were purchased from Alfa Aesar, Germany, while anhydrous $\mathrm{MgCl}_{2}$ (>99 wt.-\%) came from Magnesia, Germany. They were used to synthesize the salt mixture of $\mathrm{MgCl}_{2}-\mathrm{KCl}-\mathrm{NaCl}$ (60-20-20 mole \%). According to previous results [50], the heating of the salts was conducted as following: after vacuuming ( $\leq 30 \mathrm{mbar}, 10 \mathrm{~min}$ ), the salt mixture (with or without $\mathrm{Mg}$ additive) was heated under argon atmosphere (purity $\geq 99.999 \%$, $\mathrm{H}_{2} \mathrm{O} \leq 3 \mathrm{ppm}$ and $\mathrm{O}_{2} \leq 2 \mathrm{ppm}, 30 \mathrm{l} / \mathrm{h}$ (STP), the absolute pressure above the salts is $\sim 1.1$ bar) from room temperature to $200^{\circ} \mathrm{C}$ with a heating rate of $5{ }^{\circ} \mathrm{C} / \mathrm{min}$, then kept at $200^{\circ} \mathrm{C}$ for 1 hour to remove residual water from the hygroscopic $\mathrm{MgCl}_{2}$ salt. After that, it was heated to $700{ }^{\circ} \mathrm{C}$ and kept at this temperature for corrosion tests on the immersed alloy samples. In previous work [51], an electrochemical technique based on Cyclic Voltammetry (CV) is developed to insitu monitor the concentration of $\mathrm{MgOH}^{+}$- the main corrosive impurity in the molten chloride salts. It could assist to control the corrosive impurity and thus the corrosive rate of structural materials in the molten chloride salts. The $\mathrm{CV}$ measurements showed that the concentration of the corrosive impurity $\mathrm{MgOH}^{+}$in the salts after the heating process was $\sim 5 \times 10^{-2} \mathrm{~mol} / \mathrm{kg}$ (salt) at $700{ }^{\circ} \mathrm{C}[51]$.

Table 1 summarizes the chemical compositions of the commercial high temperature $\mathrm{Fe}-\mathrm{Cr}-\mathrm{Ni}$ based alloys (SS 310, In $800 \mathrm{H}$ and $\mathrm{Ha} \mathrm{C}-276$ ) used in this study. Additionally, the theoretical standard electromotive forces (EMF) of the main elements in their chloride salts are indicated. Chromium (high EMF value) in the Fe-Cr-Ni based alloys is preferentially corroded in molten chloride salts. Thus, Ha C-276 alloy with low $\mathrm{Cr}$ is selected for corrosion test, yet the high $\mathrm{Ni}$ content will increase the prices of the alloys. Therefore, SS 310 alloy with low Ni is selected for comparison. These three alloys were tested in the molten chloride salt mixture at $700^{\circ} \mathrm{C}$ before and showed severe corrosion [21]. In this study, they are tested in molten $\mathrm{MgCl}_{2}-\mathrm{NaCl}-\mathrm{KCl}$ (6020-20 mole \%) with 1 wt. \% Mg metal (> 99.95 wt.-\%, Alfa Aesar, Germany) addition in order to explore the role of $\mathrm{Mg}$ additive in mitigating corrosion of the alloys in contact with the molten 
salts. Before each test, samples of each commercial Fe-Cr-Ni alloy (size: $10 \mathrm{~mm} \times 10 \mathrm{~mm} \times 10 \mathrm{~mm}$ ) were ground by sandpapers $(600,800$ and $1200 \#)$, and washed by distilled water and acetone.

Table 1. Compositions of the commercial alloys (main elements) (wt.-\%), and the theoretical standard electromotive forces (EMF) in their chloride salts

\begin{tabular}{|c|c|c|c|c|c|c|c|}
\hline Alloy & $\mathrm{Fe}$ & $\mathrm{Ni}$ & $\mathrm{Cr}$ & $\mathrm{Mn}$ & $\mathrm{Si}$ & Mo & W \\
\hline SS 310 & Balance & 17.51 & 25.87 & 2.02 & 2.36 & $\ldots$ & $\ldots$ \\
\hline In $800 \mathrm{H}$ & Balance & 29.40 & 20.84 & 1.06 & 0.78 & $\ldots$ & $\ldots$ \\
\hline Ha C-276 & 6.15 & Balance & 15.38 & 0.40 & 0.03 & 14.12 & 5.89 \\
\hline $\mathrm{EMF}(\mathrm{V})$ [52] & $\begin{array}{l}1.12_{800^{\circ} \mathrm{C}} \\
\left(\mathrm{Fe} / \mathrm{FeCl}_{2}\right)\end{array}$ & $\begin{array}{l}0.88_{800^{\circ} \mathrm{C}} \\
\left(\mathrm{Ni} / \mathrm{NiCl}_{2}\right)\end{array}$ & $\begin{array}{l}1.35_{800^{\circ} \mathrm{C}} \\
\left(\mathrm{Cr} / \mathrm{CrCl}_{2}\right)\end{array}$ & $1.81_{800^{\circ} \mathrm{C}}$ & $1.47_{100^{\circ} \mathrm{C}}$ & $0.47_{550^{\circ} \mathrm{C}}$ & $0.43_{300^{\circ} \mathrm{C}}$ \\
\hline$\Delta \boldsymbol{G}_{\boldsymbol{M} \boldsymbol{C} \boldsymbol{C l}_{\boldsymbol{x}}}^{\mathbf{0}}(\mathrm{kJ} / \mathrm{mol})$ & $-216_{800^{\circ} \mathrm{C}}$ & $-170_{800^{\circ} \mathrm{C}}$ & $-261_{800^{\circ} \mathrm{C}}$ & & & & \\
\hline \multicolumn{8}{|c|}{$\begin{array}{l}\boldsymbol{E} \boldsymbol{M F}=\frac{-\Delta \boldsymbol{G}_{M C l_{x}}^{0}}{\boldsymbol{n F}} \text {, where } \Delta \boldsymbol{G}_{\boldsymbol{M} \boldsymbol{C l}_{\boldsymbol{x}}}^{\mathbf{n}} \text { is the standard free energy of formation of pure metal chloride }\left(\mathrm{MCl}_{\mathrm{x}}\right) \\
\text { liquid, } F \text { is the faraday constant, } 96485 \mathrm{~s} \mathrm{~A} / \mathrm{mol}, n \text { is the number of faradays involved in the } \\
\text { electrochemical reactions. }\end{array}$} \\
\hline
\end{tabular}

Table 2 gives the chemical compositions of two alumina-forming $\mathrm{Fe}-\mathrm{Cr}-\mathrm{Al}$ alloys. Compared with Fe-Cr-Ni based alloys, Fe-Cr-Al based alloys are less expensive. Addition of minor elements like $\mathrm{Y}, \mathrm{Zr}$ and $\mathrm{Hf}$ has been reported to improve the oxide scale adherence [53-54]. Since the atmosphere used in the experiment is inert, these two alumina forming alloys were pre-oxidized in air to form a protective oxide layer before exposure to the molten salts. Two pieces of each alloy with a thickness of $1.5 \mathrm{~mm}$ were ground by $1200 \#$ sandpaper followed by washing with distilled water and acetone. The samples were isothermally stored at $800^{\circ} \mathrm{C}$ for $15 \mathrm{~h}$ in a furnace in order to form the protective oxide scale. After pre-oxidation, one piece of each alloy was used for surface and cross section characterization by SEM/EDX. Another pre-oxidized piece was used for corrosion test in molten chloride salts (without addition of Mg corrosion inhibitor).

Table 2. Nominal compositions of two alumina-forming Fe-Cr-Al alloys (wt.-\%)

\begin{tabular}{llllll}
\hline Alloys & $\mathrm{Fe}$ & $\mathrm{AL}$ & $\mathrm{Cr}$ & $\mathrm{Y}$ & $\mathrm{Zr}$ \\
\hline AF-1 & Balance & 8 & 16 & 0.5 & --- \\
AF-2 & Balance & 8 & 16 & -- & 0.5 \\
\hline
\end{tabular}

\subsection{Immersion tests}

Figure 2 shows the schematic diagram of the experimental set-up for immersion tests of the selected alloys in molten chloride salts. High temperature resistant glassy carbon crucibles 
purchased from HTW Germany (Sigradur® G, GAZ 4) were used to avoid any reaction of the molten salts with the crucible. During the experiments, the temperature of the molten salts under an argon atmosphere was controlled by a thermocouple close to the molten salts. As shown in Fig. 2, in glassy carbon crucibles with a diameter of $30 \mathrm{~mm}$ and a height of $107 \mathrm{~mm}$, the commercial Fe-Cr-Ni alloy samples were completely immersed into the molten $\mathrm{MgCl}_{2}-\mathrm{NaCl}-\mathrm{KCl}$ (60-20-20 mole \%, 50 g) with 1 wt.-\% Mg corrosion inhibitor, while the Fe-Cr-Al alloys were exposed in molten $\mathrm{MgCl}_{2}-\mathrm{NaCl}-\mathrm{KCl}$ without $\mathrm{Mg}$ corrosion inhibitor. In order to ensure that all the surfaces of the samples are in full contact with the molten chlorides, they are hung into the molten salts using a Ni-wire and nickel tube placed across the glassy carbon crucible. After $500 \mathrm{~h}$ exposure at $700^{\circ} \mathrm{C}$, the furnace was slowly cooled down under argon atmosphere. The samples were removed and cleaned using distilled water.

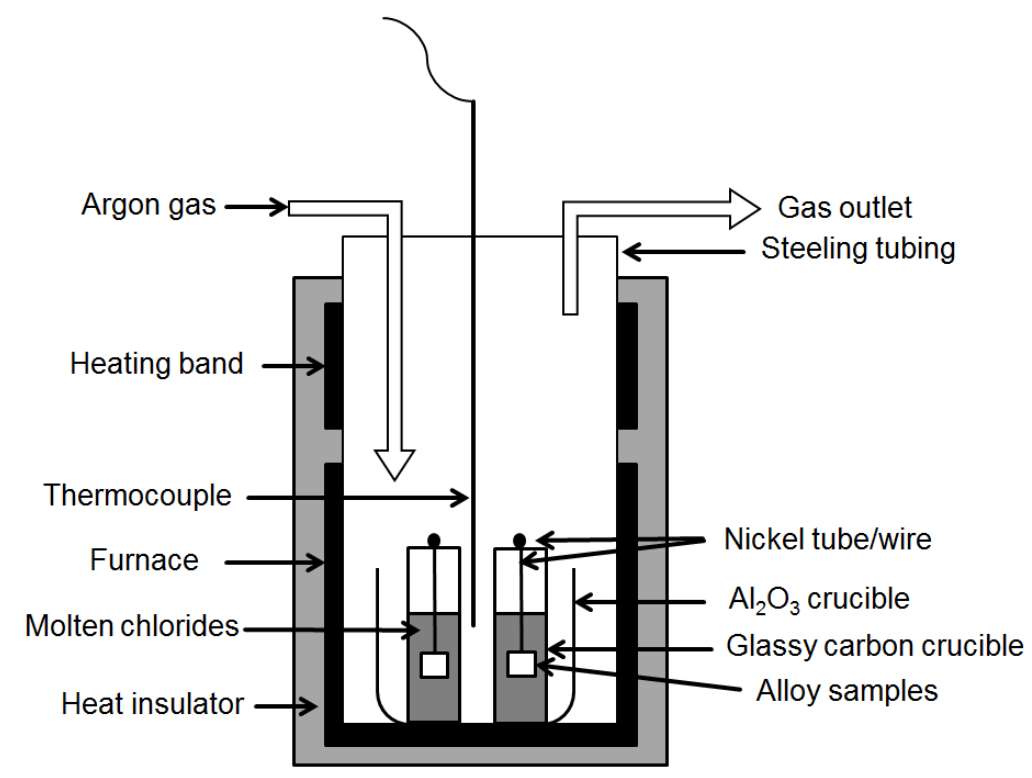

Fig. 2 Schematic diagram of experimental set-up for immersion tests in molten $\mathrm{MgCl}_{2}-\mathrm{KCl}-\mathrm{NaCl}$.

\subsection{Corrosion analysis}

In order to analyze the microstructure of the samples after corrosion tests, the salts deposited on the sample surfaces were carefully removed with a small brush while the corrosion products (i.e., oxides) remained on the surface. After cleaning the samples, scanning electron microscopy (SEM) and energy-dispersive X-ray spectroscopy (EDX) were employed to analyze the surface and cross section of each sample. For the cross section analysis of the exposed alloys, nickel was deposited by electroplating to protect the surface layer during polishing. SEM-EDX examination was performed with Philips XL40 equipped with a SAMX-EDX system. 
Moreover, the phase composition of the corrosion products was analyzed using a Seyfert C3000 powder diffractometer ( $\mathrm{Cu}$ Ka radiation, $\lambda: 0.15405 \mathrm{~nm}$ ) operating at $40 \mathrm{kV}$ and 25mA from $5^{\circ}$ to $90^{\circ}$ at a step size $(\Delta 2 \theta)$ of $0.05^{\circ}$ and a counting time of $20 \mathrm{~s}$ per step. The X-ray beam shape was in point focus with a beam size of $1.5 \mathrm{~mm}$.

Corrosion rate is a typical parameter used to characterize the speed at which metals deteriorate in molten salts system. Usually electrochemical tests (e.g., potentiodynamic polarization, electrochemical impedance spectroscopy) and gravimetric weight loss are employed to measure it $[16,20-21,25,28]$. Electrochemical tests can in-situ measure the corrosion rate by applying a current or potential on the test cell. It is rapid but sometimes expensive equipment and knowledge of electrochemistry are required [28]. Gravimetric weight loss method takes hundreds of hours in order to calculate an average corrosion rate from the weight change over the exposure time. However, factors including the formation of corrosion products (oxides) and residual salts stayed in the corrosion pores, grain boundary depletion of $\mathrm{Cr}$, result in the inaccuracy of the results $[9,21]$. Therefore, the maximum corrosion depths measured from the cross sections of exposed samples are employed to calculate the corrosion rates in this study. Based on the maximum measured corrosion depth from cross section by SEM-EDX, the average corrosion rate $(C R, \mu \mathrm{m} /$ year $)$ was calculated by the following Eq.1 [29,30]:

$C R=(365 \times 24) \cdot \frac{\mathrm{x}}{t_{0}}$

Eq. 1

Where $t_{0}$ is the exposure time (h), $x$ is the measured maximum corrosion depth ( $\mu \mathrm{m}$, from cross section) after $t_{0} \mathrm{~h}$ exposure.

\section{Results}

\subsection{Corrosion tests of Fe-Cr-Ni based alloys in molten chlorides with Mg}

\subsubsection{Surface characterization}

The plan-view surfaces of the samples after corrosion tests in $\mathrm{Mg}$ added molten chloride salts are shown in Fig. 3. The surfaces of all exposed alloys are entirely covered by polyhedralshaped crystals. These crystals observed on the surface of SS 310, Incoloy $800 \mathrm{H}$ and Hastelloy C-276 (Fig. 3 a-c), as evidenced by quantitative EDS analysis shown in Fig. 4, consist mainly of $\mathrm{Mg}$ and $\mathrm{O}$. Further measurements by XRD indicated that the crystals formed on surface are enriched with cubic MgO (JCPDS: 87-652), as shown in Fig. 5. Regions enriched with metallic Ni are observed on the surface of the Hastelloy C-276 (bright aspect ratio, Fig. 3(c), 
inlet), as evidenced by EDS-mapping. Fig. 3d shows the bare metal surface of Hastelloy C-276 obtained after the $\mathrm{MgO}$ layer was mechanically removed. The alloy surface is porous. The sizes of the pores which formed during exposure are around $1 \mu \mathrm{m}$.
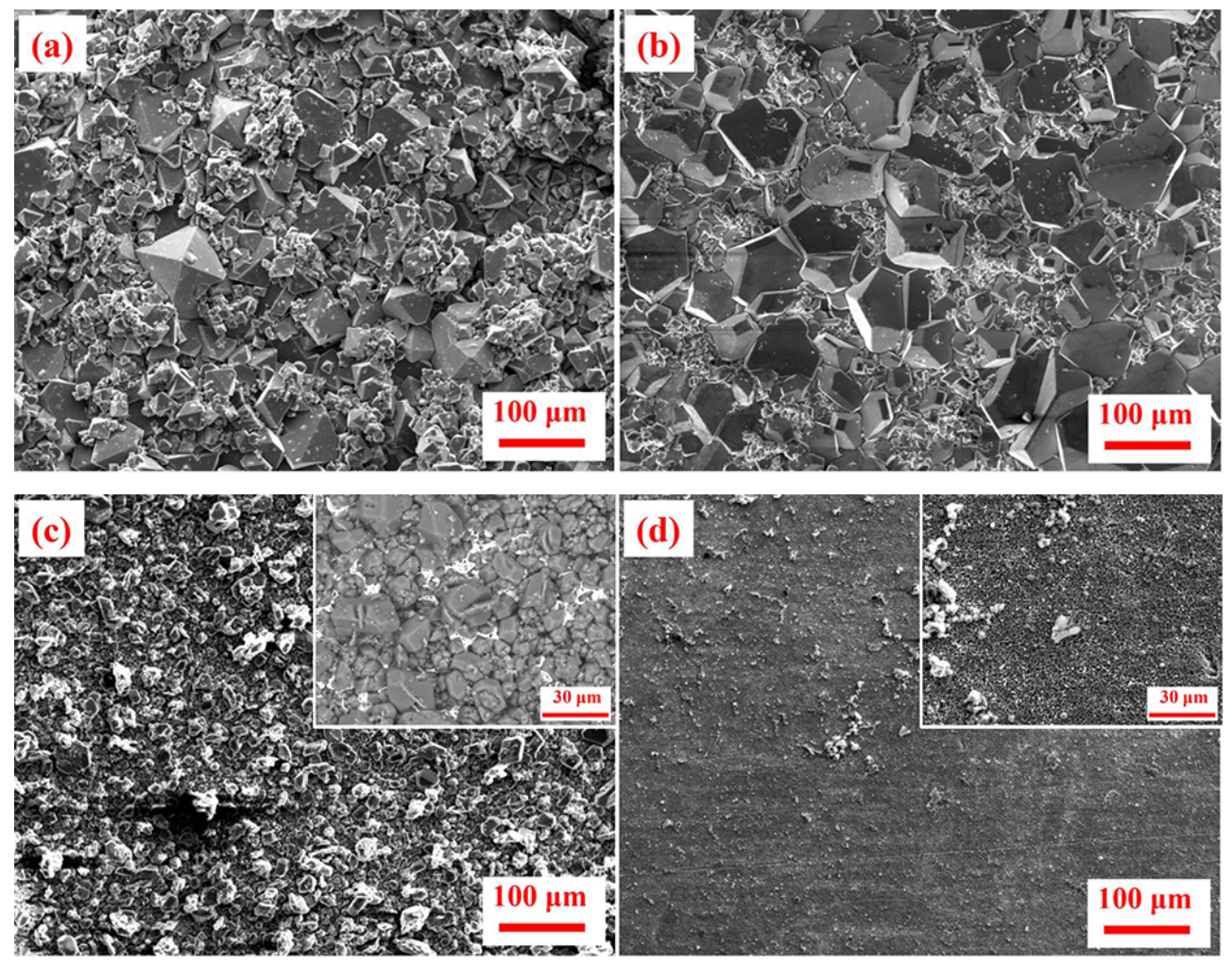

Fig. 3 Surface morphologies of tested alloys after exposure to molten $\mathrm{MgCl}_{2}-\mathrm{KCl}-\mathrm{NaCl}$ with $1 \mathrm{wt} . \% \mathrm{Mg}$ addition at $700{ }^{\circ} \mathrm{C}$ for 500 h. (a) SS 310, (b) In $800 \mathrm{H}$ and (c) Ha C-276 and (d) the same Ha C-276 after mechanical removal of the $\mathrm{MgO}$ layer. Inlet in (c) and (d) show regions enriched with metallic Ni (bright regions) and porous surface, respectively.

\begin{tabular}{|c|c|c|c|c|c|c|c|}
\hline 6000 & & & & Element & Line & wt.\% & at. \% \\
\hline \multirow{4}{*}{ 응 4000} & & & & $\mathrm{O}$ & $\mathrm{Ka}$ & 28.01 & 38.10 \\
\hline & & & & $\mathrm{Na}$ & $\mathrm{Ka}$ & 1.89 & 1.79 \\
\hline & $\mathrm{Mg}$ & & & $\mathrm{Mg}$ & $\mathrm{Ka}$ & 65.31 & 58.47 \\
\hline & & & & $\mathrm{Si}$ & $\mathrm{Ka}$ & 0.5 & 0.39 \\
\hline 志 3000 & & & & $\mathrm{Cl}$ & $\mathrm{Ka}$ & 0.32 & 0.19 \\
\hline & & & & $\mathrm{Cr}$ & $\mathrm{Ka}$ & 0.22 & 0.09 \\
\hline 2000 & & & & $\mathrm{Mn}$ & $\mathrm{Ka}$ & 0.05 & 0.02 \\
\hline & ${ }_{\mathrm{NB}}^{\mathrm{Mn}}$ & & & $\mathrm{Fe}$ & $\mathrm{Ka}$ & 0.08 & 0.03 \\
\hline 1000 & cr & & & $\mathrm{Ni}$ & $\mathrm{Ka}$ & 1.57 & 0.58 \\
\hline & $\begin{array}{ll}\text { fe } & \text { Mo } \\
\text { w Mo } \mathrm{Ml}\end{array}$ & $\mathrm{MnFe}$ & & Mo & La & 0.77 & 0.17 \\
\hline & $\mathrm{Si} \quad \mathrm{Cl}$ & $\mathrm{Cr} \mathrm{CrMnFeNi} \mathrm{Ni}$ & w & W & La & 1.27 & 0.15 \\
\hline
\end{tabular}

Fig. 4 EDS chemical composition measurement of the surface of exposed Ha C-276 after the corrosion experiment with 1 wt.-\% Mg addition. 


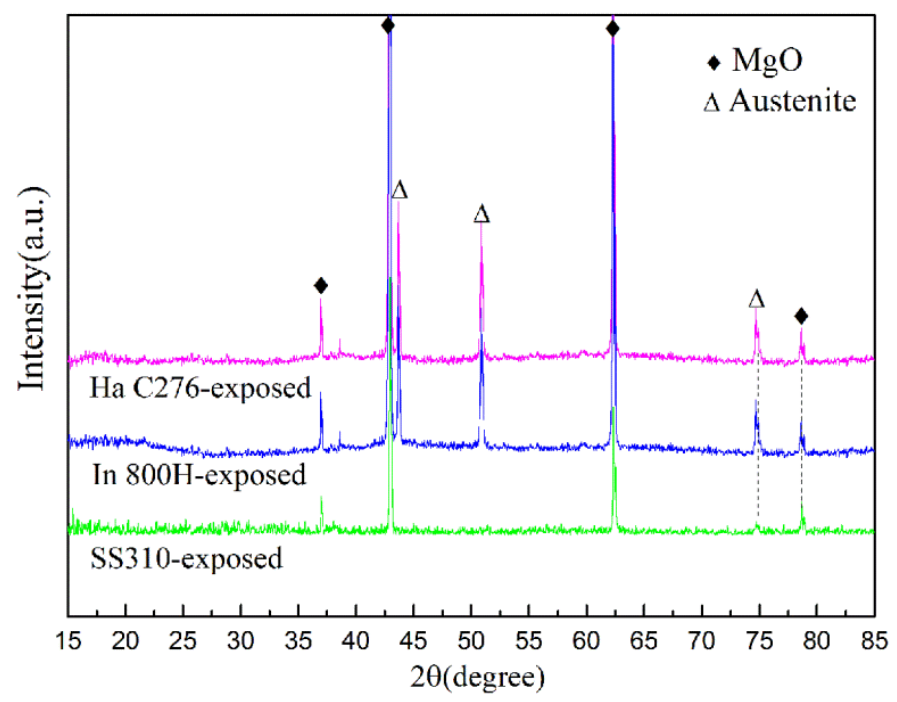

Fig. 5 XRD patterns of three tested alloys after the corrosion experiment with $1 \mathrm{wt} . \% \mathrm{Mg}$ addition.

\subsubsection{Cross sections analysis}

Cross-section SEM back scattered electron (BSE) images of the three tested Fe-Cr-Ni based alloys are shown in Fig. 6. A thick and dense $\mathrm{MgO}$ layer is attached on the surface of all exposed samples (Figs. 6b, d and f). The thickness of the MgO layer formed on SS 310, In 800 $\mathrm{H}$ and $\mathrm{Ha} \mathrm{C}-276$ is approximately $30 \pm 15 \mu \mathrm{m}$. Underneath the $\mathrm{MgO}$ layer, a porous and uniform corroded layer, which shows similar morphology and thickness in SS 310 and $\ln 800 \mathrm{H}$, is visible, while only a thin corrosion layer is evident at the surface of $\mathrm{Ha} \mathrm{C}-276$. The measured maximum corrosion depth of SS 310 , In $800 \mathrm{H}$ and Ha C-276 is $17 \pm 4,15 \pm 3$ and $1.7 \pm 0.5 \mu \mathrm{m}$, respectively.

Fig. 7 and Fig. 8 show the respective EDS elemental mappings of SS 310 and In $800 \mathrm{H}$ after exposure to molten $\mathrm{MgCl}_{2}-\mathrm{KCl}-\mathrm{NaCl}$ including $\mathrm{Mg}$ addition, at $700^{\circ} \mathrm{C}$ for $500 \mathrm{~h}$. In the SS 310 sample (Fig. 7) the corrosion layer is depleted in $\mathrm{Cr}$ and the remains mainly consist of $\mathrm{Fe}$ and $\mathrm{Ni}$. Pores with the size in the range of 1-3 $\mu \mathrm{m}$ are widely distributed among the corroded areas. In the In $800 \mathrm{H}$ sample shown in the elemental mapping (Fig. 8) and the line scan (Fig. 9), a heavy depletion of $\mathrm{Cr}$, a slight depletion of $\mathrm{Fe}$ and an enrichment of $\mathrm{Ni}$ towards the surface is visible in the corrosion layer. Besides, some $\mathrm{MgO}$ clusters are detected inside of the corrosion layers. Based on the morphologies and elemental distribution in the corroded area, SS 310 and In 800 $\mathrm{H}$ show similar corrosion behavior. 

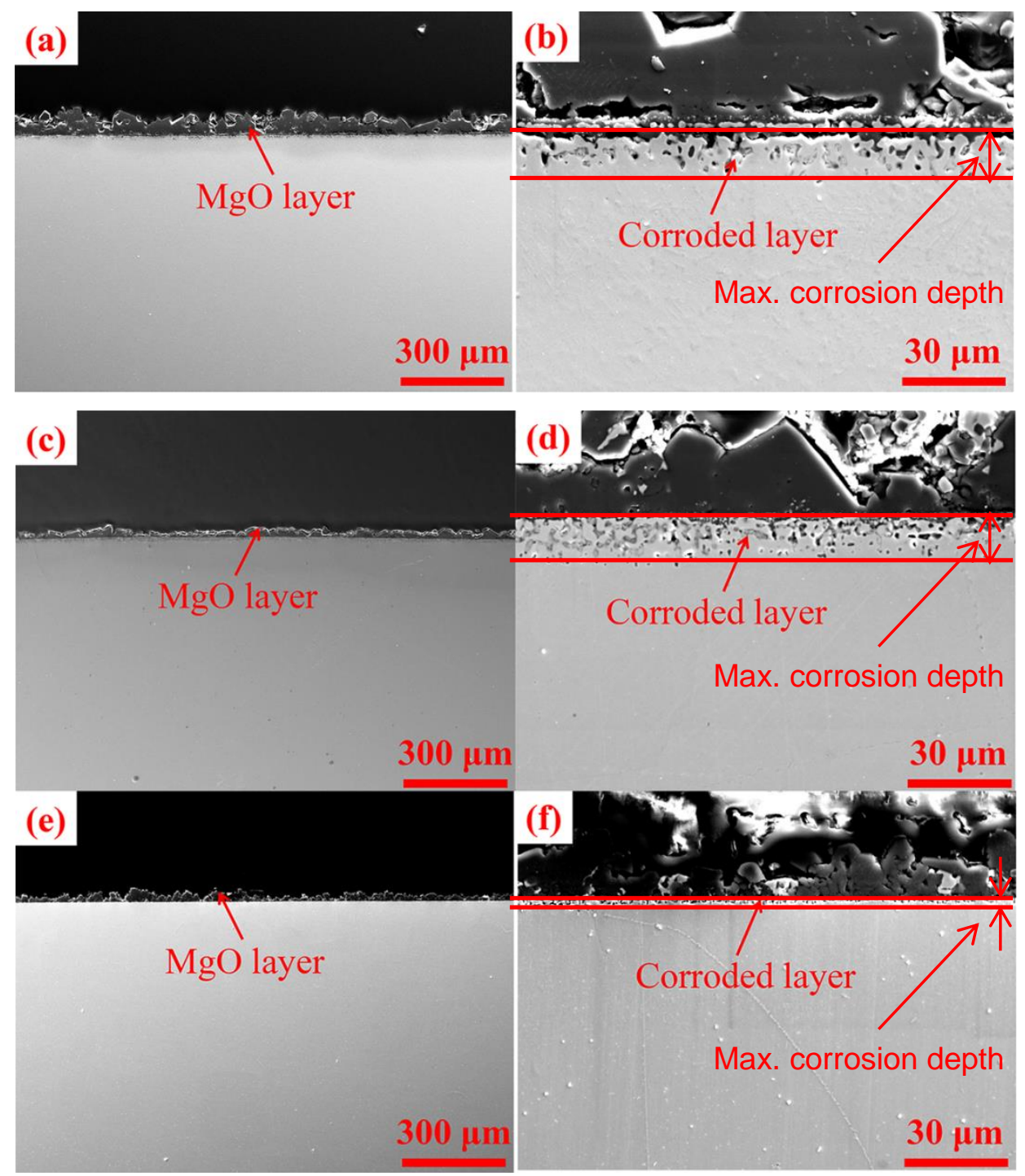

Fig. 6 SEM-BSE cross section images of the alloys SS 310 ( $a$ and b), In $800 \mathrm{H}$ (c and d) and Ha C-276 (e and f) after the corrosion experiment with $1 \mathrm{wt} . \mathrm{\%} \mathrm{Mg}$ addition ( $\mathrm{a}, \mathrm{c}, \mathrm{e}: 100 \mathrm{X} ; \mathrm{b}, \mathrm{d}$, f: 1000X). The maximum corrosion depths are measured and shown in $(b, d, f)$.

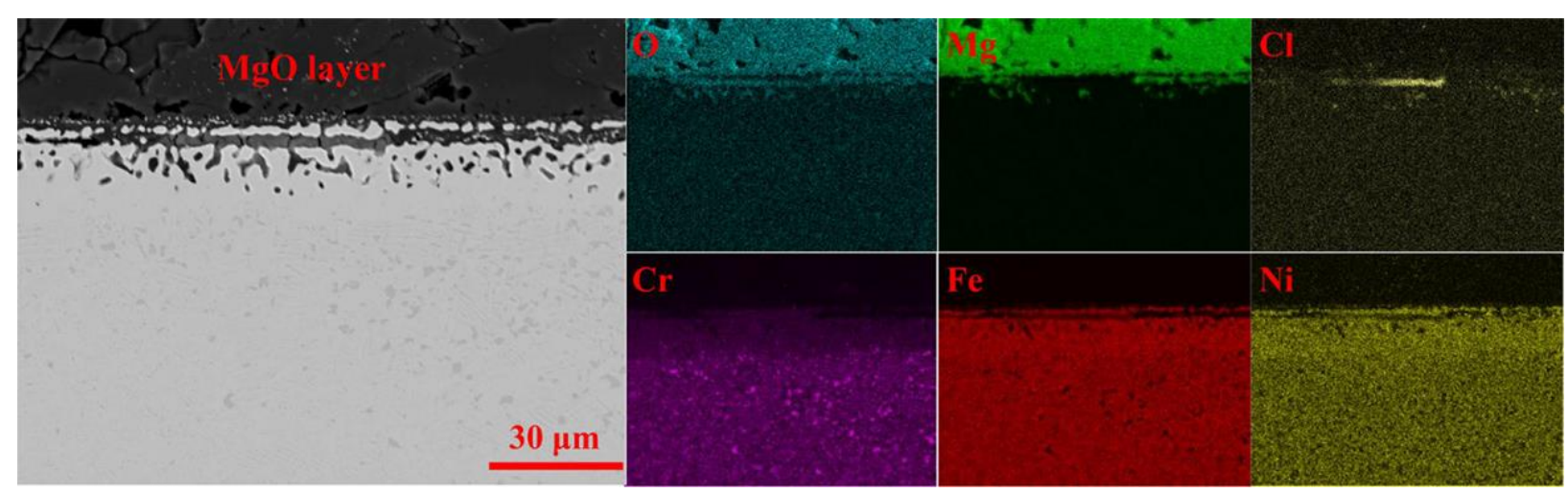

Fig. 7 SEM-BSE image and EDS elemental mapping of SS 310 after the corrosion experiment with $1 \mathrm{wt} . \% \mathrm{Mg}$ addition. 


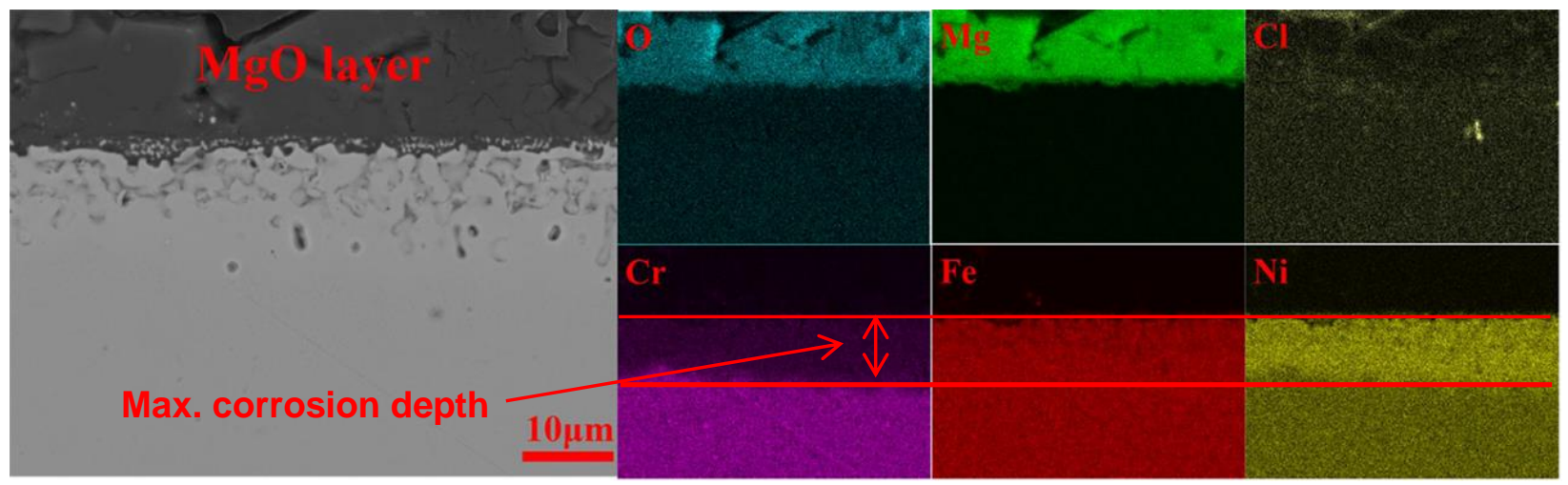

Fig. 8 SEM-BSE image and EDS elemental mapping of In $800 \mathrm{H}$ after the corrosion experiment with $1 \mathrm{wt} . \% \mathrm{Mg}$ addition. The maximum corrosion depth is measured based on EDS mapping of $\mathrm{Cr}$, Fe and $\mathrm{Ni}$.

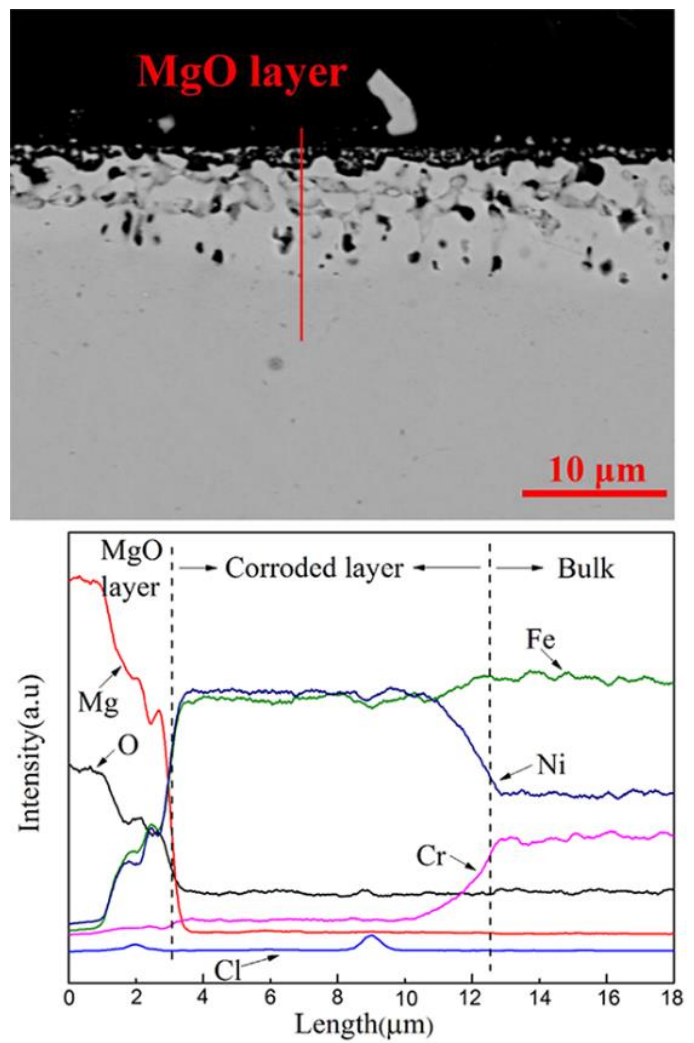

Fig. 9 SEM-BSE image and EDS line scanning profiles at the cross section of In $800 \mathrm{H}$ after the corrosion experiment with $1 \mathrm{wt} . \mathrm{-} \% \mathrm{Mg}$ addition.

Compared with SS 310 and In $800 \mathrm{H}$, only minor corrosion attack, with a depth of $1.7 \pm 0.5 \mu \mathrm{m}$, is observed on Ha C-276. EDS elemental mapping of the cross section of Ha C-276 is shown in Fig. 10. $\mathrm{Mg}$ and $\mathrm{O}$ are present as the main elements in the precipitate layer above the alloy surface. Below, a corrosion layer enriched with $\mathrm{Cr}$ and Mo is detected (Fig. 10 and Fig. 11). In the EDS elemental mapping (Fig. 10), it is clear that Mo and $\mathrm{Cr}$ are also enriched at the grain boundaries in the bulk of the sample. The Mo and $\mathrm{Cr}$ enrichment found in the corroded layer might be due to a grain boundary reaching the surface (see Fig. 10). 


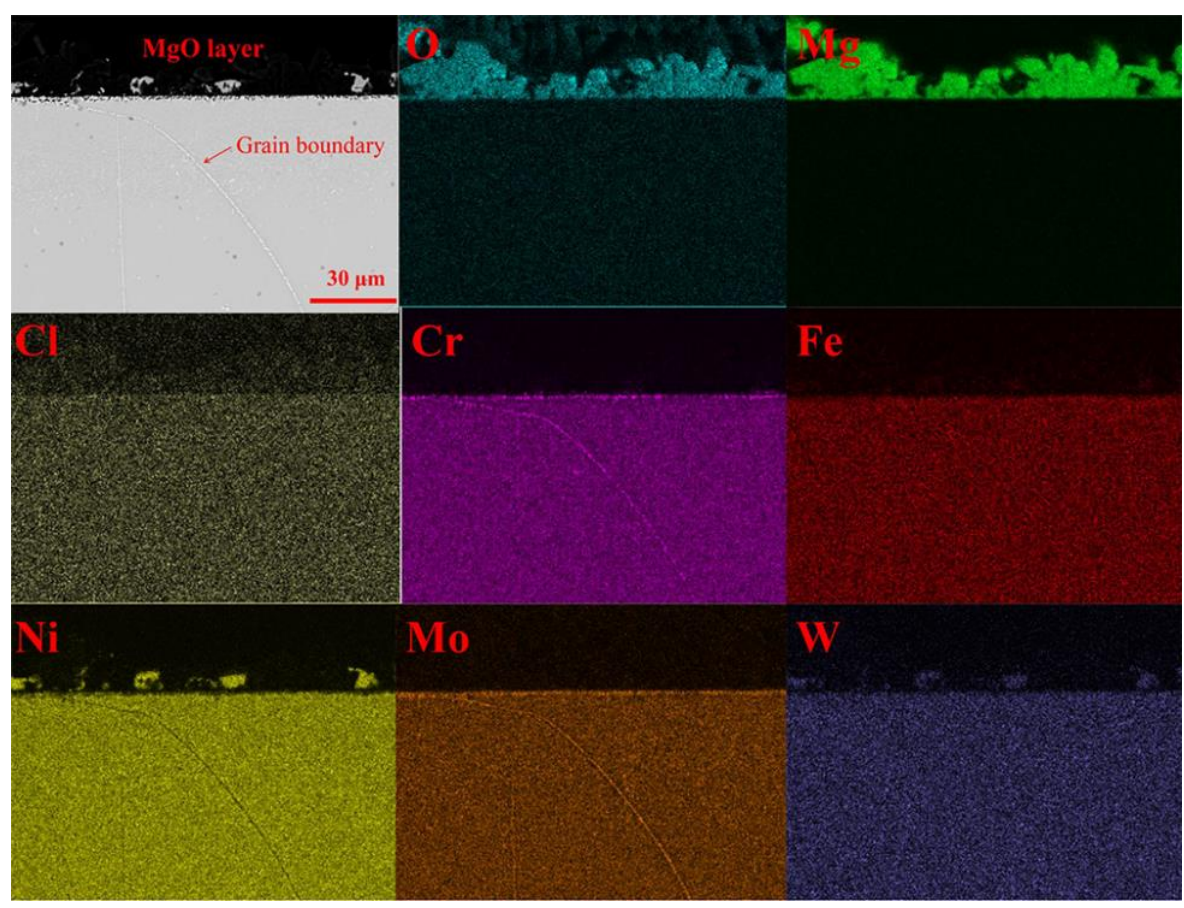

Fig.10 SEM-BSE cross section image and EDS elemental mapping of Ha C-276 after the corrosion experiment with 1 wt.-\% Mg addition.
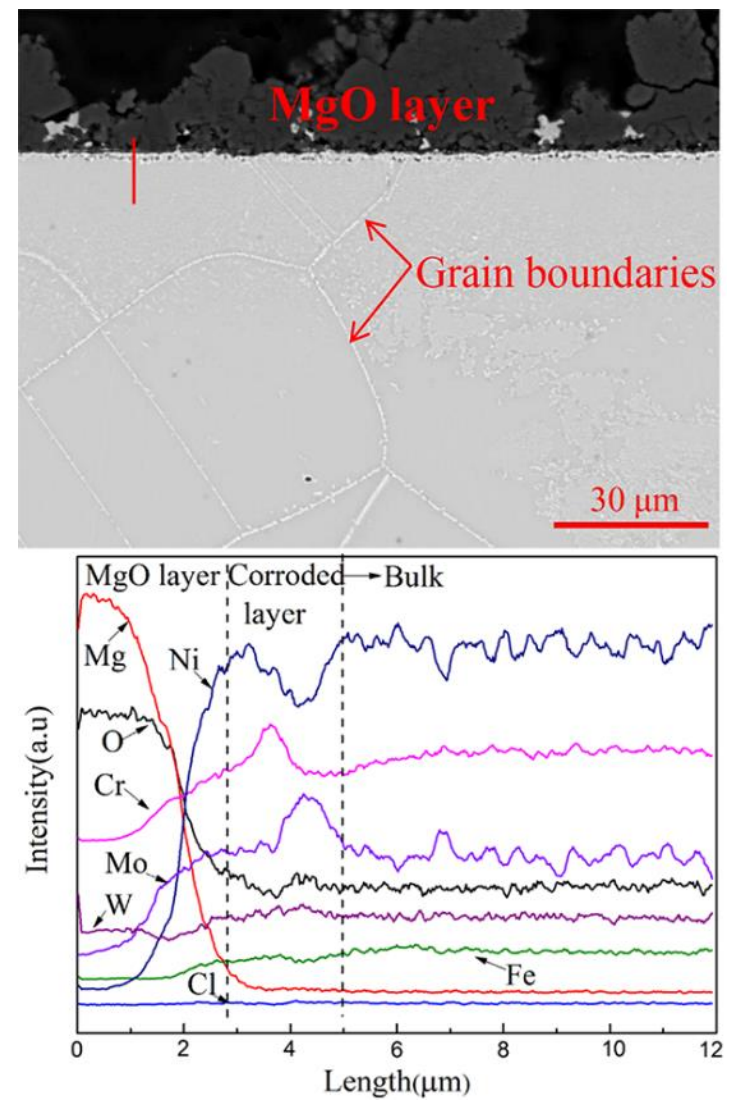

Fig. 11 SEM-BSE cross section image (BSE) and EDS line scanning profiles at the cross section of $\mathrm{Ha} \mathrm{C}-276$ after the corrosion experiment with $1 \mathrm{wt} . \mathrm{\%} \mathrm{Mg}$ addition. 


\subsection{Corrosion test of alumina forming model alloys}

\subsubsection{Pre-oxidization}

After $15 \mathrm{~h}$ oxidation at $800^{\circ} \mathrm{C}$ in air, AF-1 and AF-2 show similar oxide scale structures. The example of the surface morphology of a dense and uniform oxide scale, formed on both model alloys, is shown in Fig. 12. Table 4 gives the measured average elemental compositions in wt.-\% of the oxide surface of both alloys. Al and $\mathrm{O}$, as evidenced by quantitative EDS analysis using $20 \mathrm{keV}$ accelerating voltage, have a relatively high concentration in the oxide scales. The measured $\mathrm{Fe}$ and $\mathrm{Cr}$ concentrations are from the substrate indicating that the alumina layer is relatively thin.

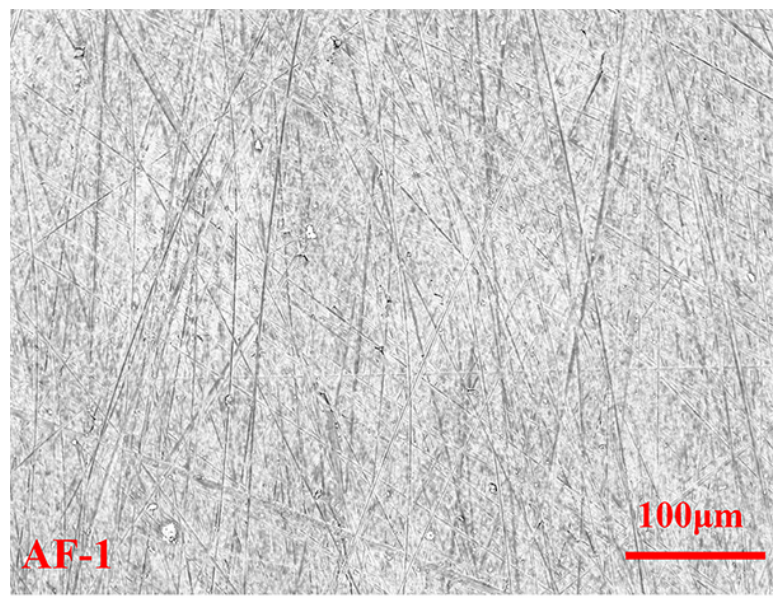

Fig.12 Surface morphology of $\mathrm{AF}-1$ after $15 \mathrm{~h}$ oxidation at $800^{\circ} \mathrm{C}$ in air.

Table 4 Measured compositions of oxide surface of both pre-oxidized samples (wt.\%).

\begin{tabular}{lllllll}
\hline Alloys & $\mathbf{O}$ & Al & Fe & $\mathbf{C r}$ & Y & Zr \\
\hline AF-1 & 36.77 & 45.1 & 8.26 & 9.14 & 0.73 & -- \\
AF-2 & 38.08 & 44.48 & 11.17 & 5.68 & -- & 0.59 \\
\hline
\end{tabular}

The EDS elemental mapping of cross section of the oxide scale (AF-1) is shown in Fig. 13. The surface oxide layer is rich in $\mathrm{Al}$ and $\mathrm{O}$, as suggested by the first EDS analysis of the surface, with a few $\mathrm{Cr}$ enriched points embedded in the oxide layer. Especially since chromia and alumina readily form solid solutions, this result is not surprising. No evidence of $\mathrm{Ni}$ and $\mathrm{Fe}$ in the oxide layer is visible. The measured thickness of the oxide scale is around $1.1 \mu \mathrm{m}$, and most probably is a mixture of $\theta-\mathrm{Al}_{2} \mathrm{O}_{3}$ and $\alpha-\mathrm{Al}_{2} \mathrm{O}_{3}$ like observed in previous work [55-57]. 


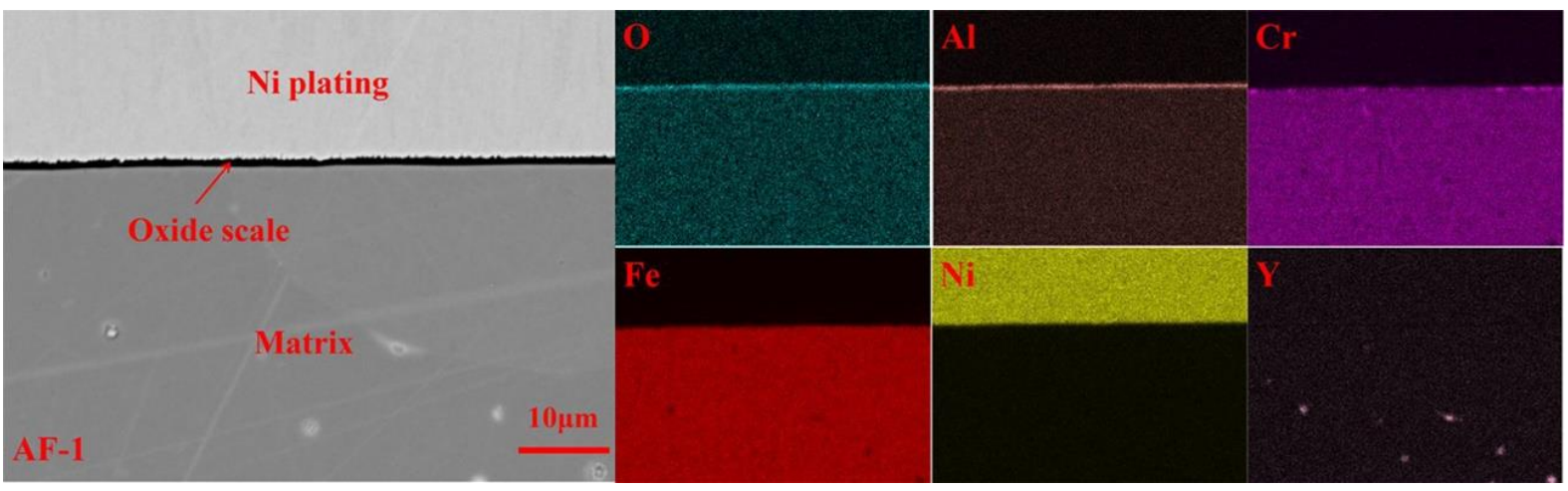

Fig.13 SEM-BSE image and EDS elemental mapping of cross section for AF-1 After $15 \mathrm{~h}$ oxidation at $800^{\circ} \mathrm{C}$ in air.

\subsubsection{Corrosion analysis}

\section{(1) Surface characterization}

Fig. 14 shows SEM images in back-scattered mode of the plan-view surfaces of both preoxidized model alloys after exposure to molten salts at $700^{\circ} \mathrm{C}$ for $500 \mathrm{~h}$ under argon atmosphere. The oxide scales formed during the pre-oxidation are still intact and no spallation is evident for both samples. However, protrusions are visible on the surface of both alloys. As evidenced by quantitative EDS and XRD analysis, shown in Figs. 14 and 15, the granular scale covering the surface is mainly $\alpha-\mathrm{Al}_{2} \mathrm{O}_{3}$ (JCPDS: 46-1212). The XRD pattern also indicates the presence of $\mathrm{MgO}$ on the surface layer as well as remains of the chloride salts.

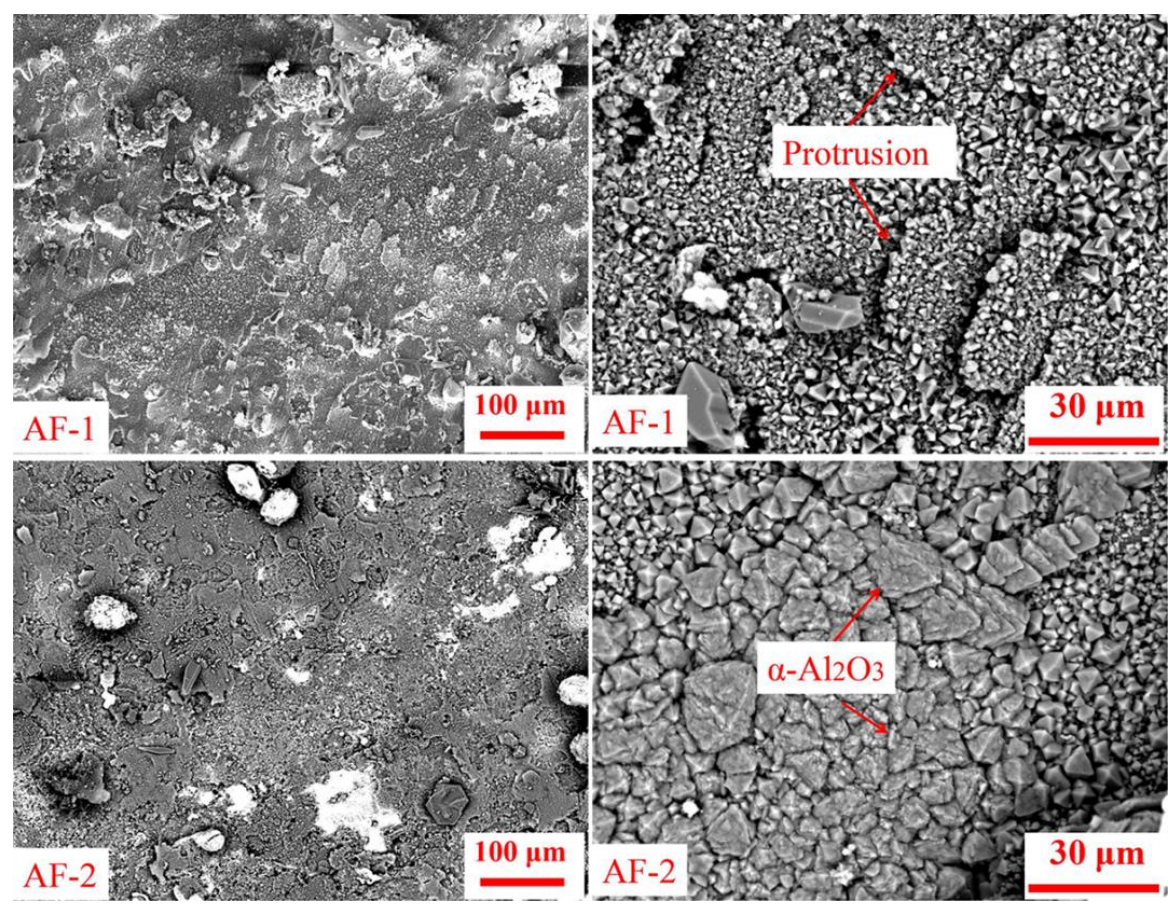

Fig. 14 Surface morphologies of AF-1 and AF-2 after exposure to molten $\mathrm{MgCl}_{2}-\mathrm{KCl}-\mathrm{NaCl}$ without $\mathrm{Mg}$ addition at $700^{\circ} \mathrm{C}$ for $500 \mathrm{~h}$. 


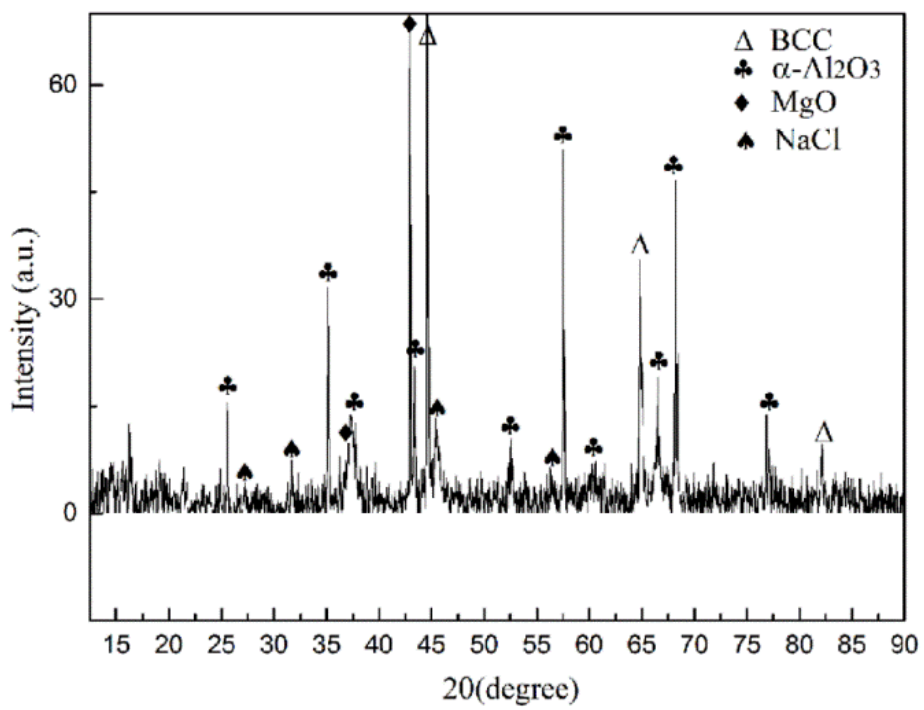

Fig. $15 \mathrm{XRD}$ pattern of AF-2 after the corrosion experiment without Mg addition (BCC lines: substrate).

\section{(2) Cross-section analysis}

Cross-sectional SEM images of the exposed alloys AF-1 and AF-2 are shown in Fig. 16. A continuous oxide layer with a thickness of around 8-10 $\mu \mathrm{m}$ was found on the surface of both samples. From the cross-sectional line scanning shown in Fig. 17, a strong intensity of $\mathrm{O}$ and $\mathrm{Al}$ through the oxide layer can be identified. There is no evident Al depletion underneath the oxide scale. Also, no $\mathrm{Cr}$ depletion or penetration of chloride salts is evident in both samples. An increase in intensity of $\mathrm{Mg}$ is visible only in the outer part of the oxide scale, which in combination with the XRD measurement (Fig. 15) of the surface indicates that MgO precipitates are formed on the surface of the aluminum oxide layer. These observations are consistent with the elemental mapping of the cross section, shown in Fig. 18. Also, it indicates that the alumina barrier successfully inhibits the outer diffusion of $\mathrm{Cr}, \mathrm{Al}$ and $\mathrm{Fe}$ and inner penetration of the chloride salts components. 


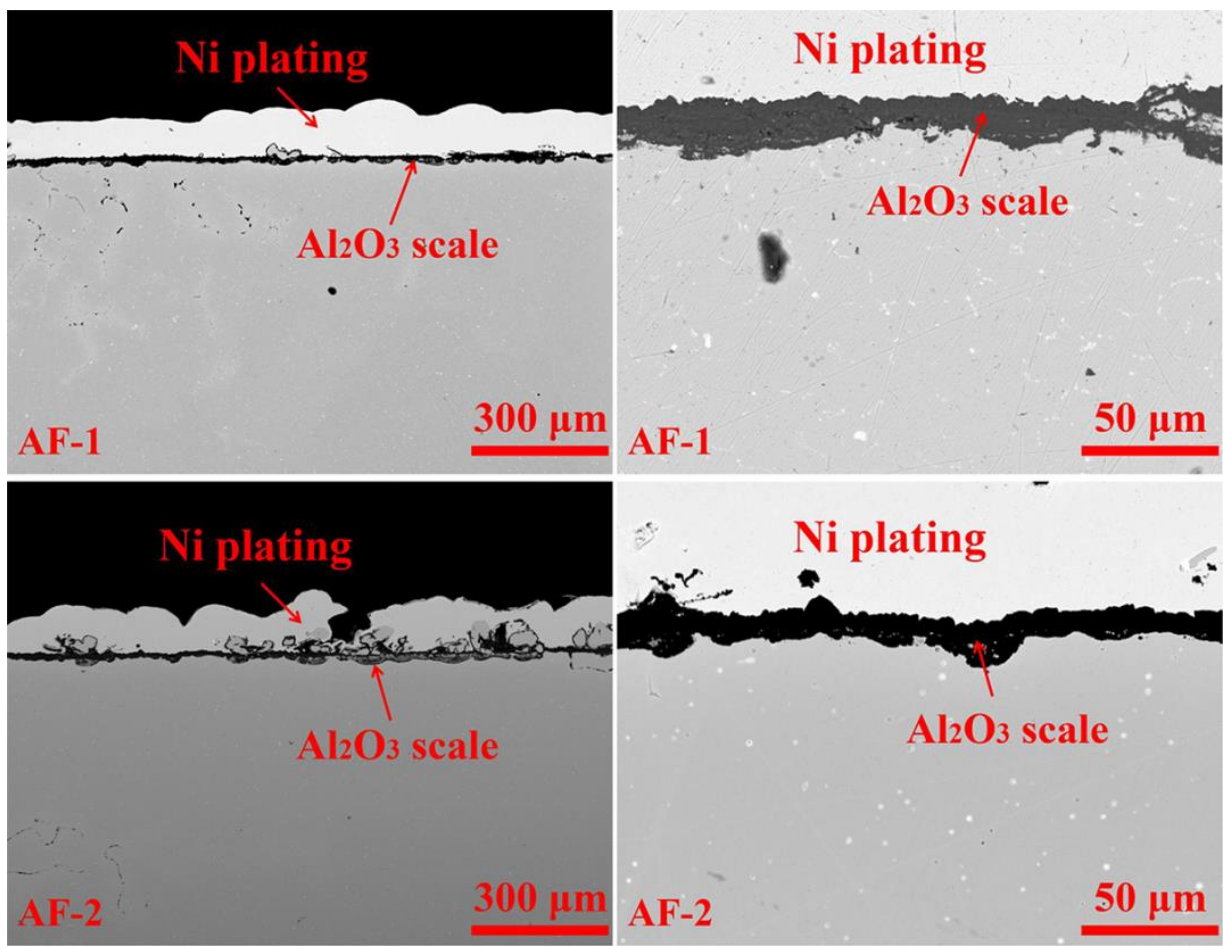

Fig. 16 SEM BSE cross section images of AF1 and AF2 after the corrosion experiment without Mg addition.
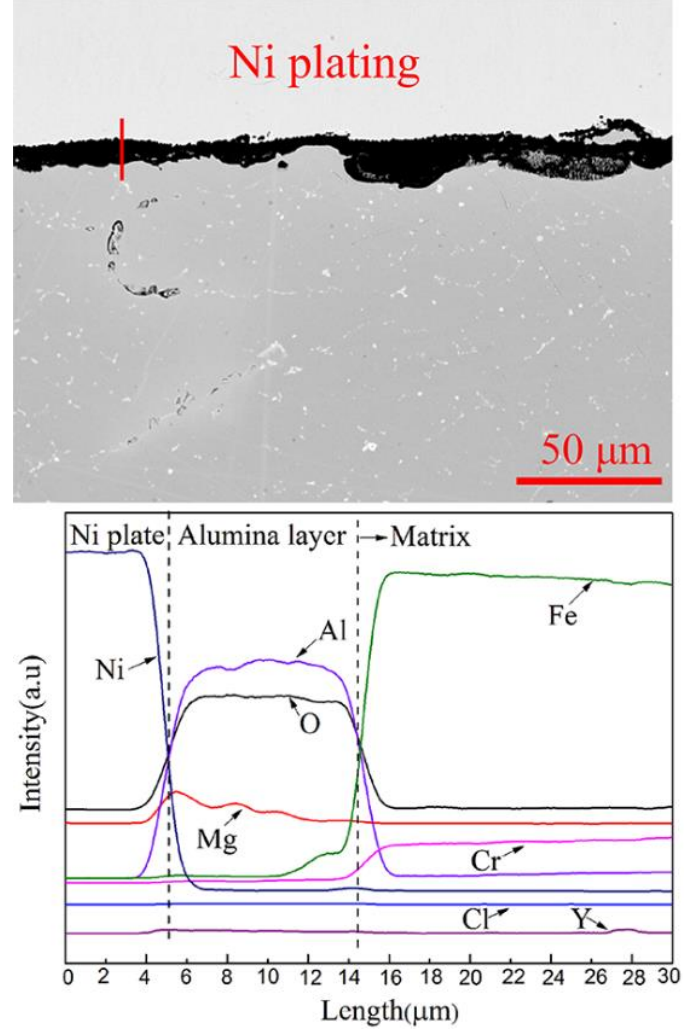

Fig. 17 Top: BSE image of the polished cross section of AF-1 after the corrosion experiment without $\mathrm{Mg}$ addition. Bottom: EDS line scanning profile of the cross section of AF-1. 


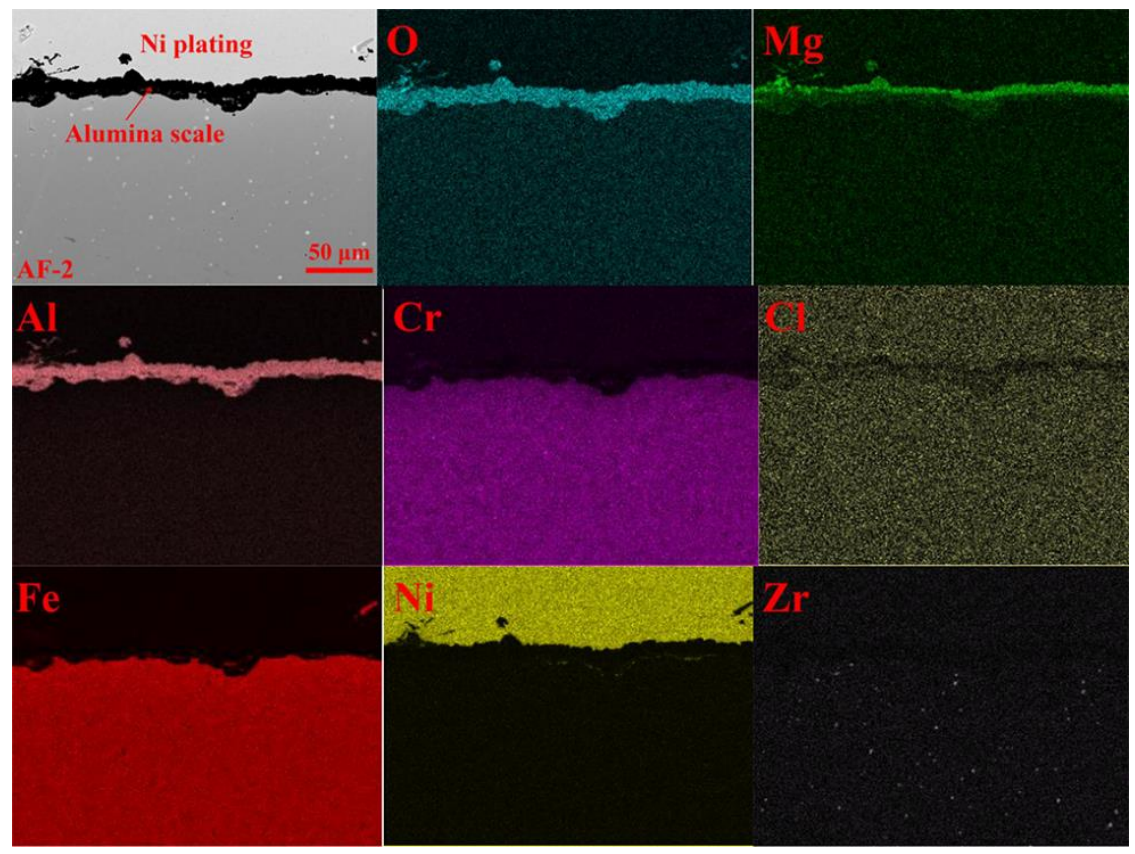

Fig. 18 SEM BSE cross section image and EDS mapping of AF-2 after the corrosion experiment without Mg addition.

\section{Discussion}

\subsection{Comparison of experimental corrosion rates with and without Mg addition}

After expose the three alloys in molten salts with $\mathrm{Mg}$ addition at $700^{\circ} \mathrm{C}$ for $500 \mathrm{~h}$, the corrosion depths of SS 310 , In $800 \mathrm{H}$ and Ha C-276 which are measured from cross section, are $17 \pm 4$, $15 \pm 3$ and $1.7 \pm 0.5 \mu \mathrm{m}$, respectively. The order of corrosion resistance of the test alloys after adding $\mathrm{Mg}$ in the molten chloride salts is: $\mathrm{Ha} \mathrm{C}-276>\ln 800 \mathrm{H} \approx \mathrm{SS} 310$. From comparison, Fig. 19 shows the SEM images of cross section of the three alloys after corrosion experiments without $\mathrm{Mg}$ addition from our previous work [21]. SS 310 and In $800 \mathrm{H}$ show serious corrosion attack, especially SS 310 with large pores and spallation of the remained corroded layer, as shown in Fig. 19(a). The order of corrosion resistance of the test alloys in molten chloride salts without $\mathrm{Mg}$ addition under inert atmosphere is: $\mathrm{Ha} \mathrm{C}-276>\ln 800 \mathrm{H}>\mathrm{SS} 310$. The measured maximum corrosion depths of SS 310, In $800 \mathrm{H}$ and Ha C-276, after immersion for 500h at $700^{\circ} \mathrm{C}$, are 100,50 and $30 \mu \mathrm{m}$, respectively [21].

The morphology of the MgO deposits on the samples surfaces, formed when using $\mathrm{Mg}$ addition, investigated in this study, are almost compact and continuous. No spallation of this $\mathrm{MgO}$ layer occurred even after grinding and polishing, which indicates the strong adherence of the $\mathrm{MgO}$ layers. According to the reference results, without $\mathrm{Mg}$ addition [21,30], a $\mathrm{MgO}$ shell that presumably originates from the decomposition of $\mathrm{MgOHCl}$ precipitates on metal surface when 
the steels are exposed to molten chloride salts contaminated with oxygen impurities. However, these $\mathrm{MgO}$ based scales peel off during exposure.

Fig. 20 compares the corrosion depths of the three alloys in absence and presence of $\mathrm{Mg}$ inhibitor. Based on the measured maximum corrosion depth and Eq. 1, the calculated corrosion rates of the three alloys exposed to chloride salts in the absence and presence of the $\mathrm{Mg}$ inhibitor are summarized in Table 5. By addition of $\mathrm{Mg}$ in the molten chloride salts, the corrosion rate can be reduced by $\sim 83 \%$ for SS 310, 70\% for In $800 \mathrm{H}$ and $\sim 94 \%$ for Ha C-276 comparing with the exposure test without Mg addition. Ha C-276 shows the best corrosion resistance to molten chloride salts at $700^{\circ} \mathrm{C}$ in the presence of $\mathrm{Mg}$ addition with a corrosion rate of $29.8 \pm 8.7$ $\mu \mathrm{m} /$ year close to the requirement for commercial applications (15 $\mu \mathrm{m} /$ year).

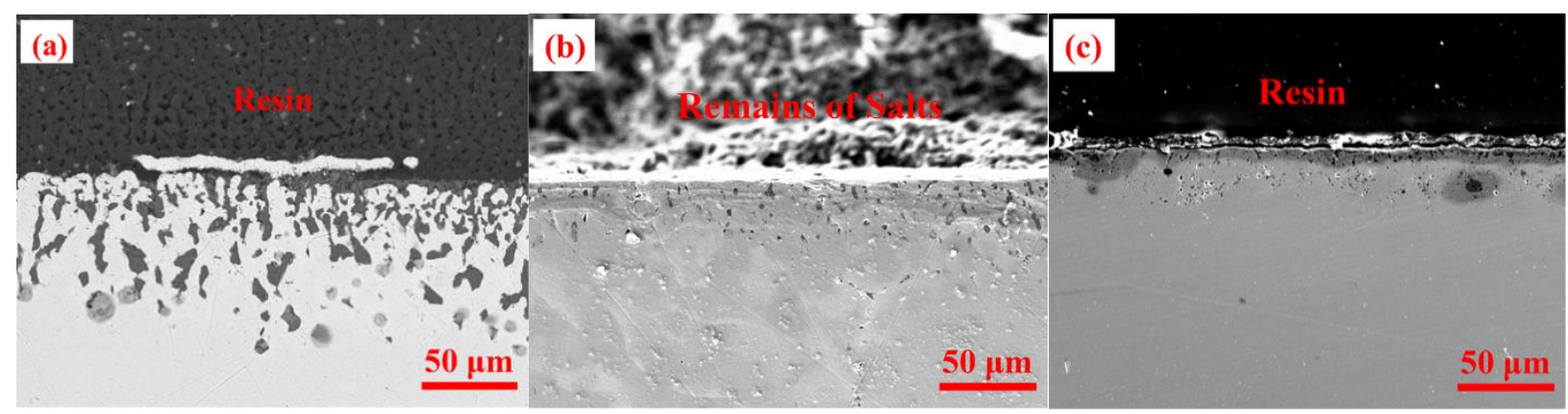

Fig. 19 SEM cross section images of (a) SS 310, (b) In $800 \mathrm{H}$ and (c) Ha C-276 after exposure to molten $\mathrm{MgCl}_{2}-\mathrm{KCl}-\mathrm{NaCl}$ at $700^{\circ} \mathrm{C}$ for $500 \mathrm{~h}$ (without $\mathrm{Mg}$ inhibitor) [21].

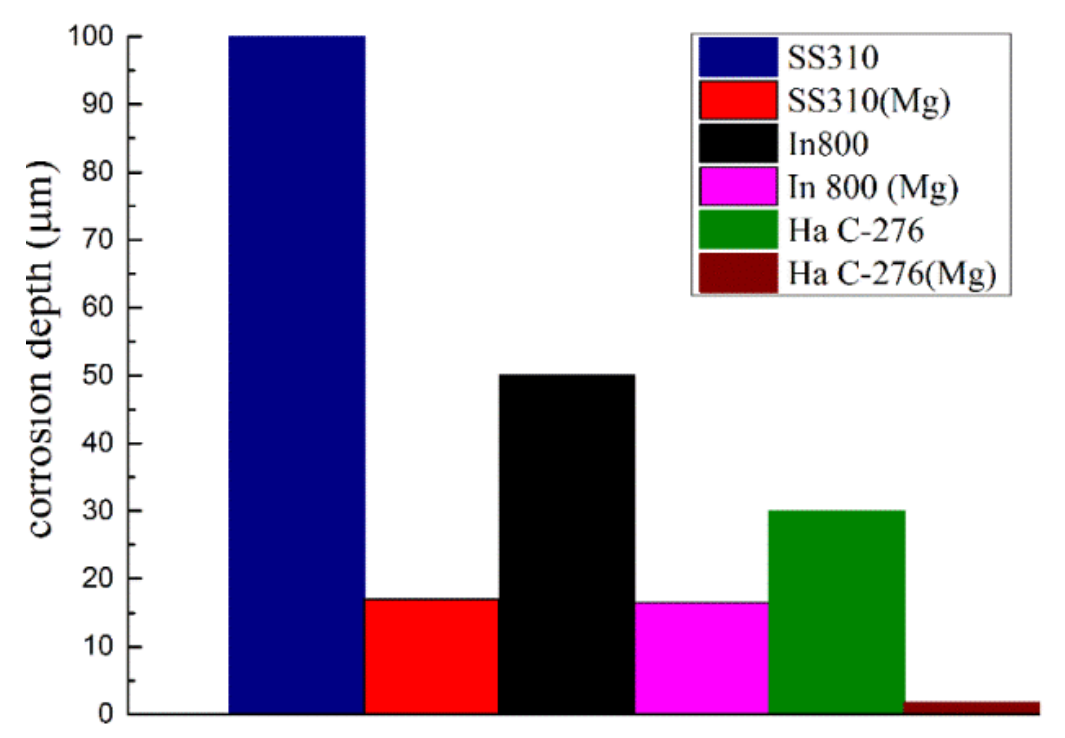

Fig. 20 Measured corrosion depth of three alloys after exposure to molten $\mathrm{MgCl}_{2}-\mathrm{KCl}-\mathrm{NaCl}$ at $700{ }^{\circ} \mathrm{C}$ for $500 \mathrm{~h}$; without and with $\mathrm{Mg}$ addition. 
Table 5 Corrosion rate of three commercial Fe-Cr-Ni alloys in $\mathrm{MgCl}_{2}-\mathrm{KCl}-\mathrm{NaCl}$ (without and with $\mathrm{Mg}$ inhibitor).

\begin{tabular}{lcc}
\hline Alloys & \multicolumn{2}{c}{ Corrosion rate $(\boldsymbol{\mu m} / \mathbf{y e a r})$} \\
& In absence of Mg addition [21] & In presence of Mg addition \\
\hline SS 310 & 1752 & $298 \pm 70(\sim 17 \%)$ \\
In 800H & 876 & $262 \pm 52(\sim 30 \%)$ \\
Ha C-276 & 526 & $29.8 \pm 8.7(\sim 6 \%)$ \\
\hline
\end{tabular}

Considering the chemical compositions of these three alloys and the EMFs of the alloying elements in Table 1, Ha C-276 alloy is a Ni-based high temperature alloy with low content of $\mathrm{Cr}$ and Fe which both are easily corroded in molten chloride salts. W and Mo have similar EMFs compared to that of $\mathrm{Ni}$ (see Table 1), which indicates the similar behavior in molten chloride salts. Besides, $\mathrm{W}$ and Mo alloying will presumably reduce the corrosion rate by lowering the diffusion of $\mathrm{Cr}$ along the grain boundaries [31,43,58]. SS 310 and $\mathrm{In} 800 \mathrm{H}$ are both Fe-based alloys with more than 20 wt.-\% Cr. The alloying elements $\mathrm{Mn}$ and Si in SS 310 are reactive towards the molten chloride salts, which has been observed in our previous work [21]. Although SS 310 contains less $\mathrm{Ni}$ than In $800 \mathrm{H}$, it has an almost similar corrosion depth compared with the latter, when Mg inhibitor is added. This may be explained with that Mg reduces the impurity level in the molten chloride salt, which is considered to be the main corrosion driver $[21,31,36]$. Moreover, the compact $\mathrm{MgO}$ layer formed on the alloy surfaces might prevent the direct contact of molten chloride salts with the alloys.

\subsection{Corrosion of Fe-Cr-Ni based alloys in molten chlorides with $\mathrm{Mg}$ addition}

\subsubsection{Thermodynamic background}

$\mathrm{Fe}, \mathrm{Cr}$ and $\mathrm{Ni}$ are the common elements for commercial alloys as structural materials. Since the free energy of formation of $\mathrm{CrCl}_{2}, \mathrm{FeCl}_{2}$ and $\mathrm{NiCl}_{2}$ is higher than $\mathrm{MgCl}_{2}$ (see Table 1 ), $\mathrm{KCl}$ and $\mathrm{NaCl}$, the corrosion of alloys cannot be caused by $\mathrm{MgCl}_{2}, \mathrm{KCl}$ and $\mathrm{NaCl}[20,43]$. Moreover, the alloys were immersed in the molten chlorides at a constant temperature and were not contact with other metals (see Fig. 2). This means that the electrochemical corrosion, galvanic corrosion and corrosion due to temperature effects cannot take place. Thus, other mechanisms driving the corrosion process, e.g. impurity-driven corrosion mechanisms, should be considered [21,23-30]. Generally, the corrosion of $\mathrm{Cr}-\mathrm{Fe}-\mathrm{Ni}$ alloys in molten chloride salts is due to oxidation and reduction reactions occurring in the system [31]. The oxidation reaction of the alloying elements (metal dissolution: $\mathrm{Cr}, \mathrm{Fe}, \mathrm{Ni}$ ) and the reduction reaction of the oxidizing impurity in the molten salt (e.g., $\mathrm{H}^{+}, \mathrm{MgOH}^{+}$) can be defined by the following Eqs. 2 and 3 : 
Oxidation of metallic element $M$ in the alloy (anode): $M=M^{m+}+m e^{-}$

Eq. 2

Reduction of oxidizing impurity $X$ in the molten salt (cathode): $\quad O x+n e^{-}=R e d$

Eq. 3

where $O x$ and Red represent the oxidant and its corresponding reductant, respectively.

Therefore, the total reaction is:

$\frac{\mathrm{n}}{\mathrm{m}} M+O x \rightleftharpoons \frac{\mathrm{n}}{\mathrm{m}} M^{m+}+R e d$

Eq. 4

In order to push the reaction towards the right side (i.e., corrosion of the alloys), the driving force of the reaction, i.e., the Gibbs free energy of formation $\left(\Delta G_{F}\right)$, should be negative. For an electrochemical reaction, the following function is applied to calculate the Gibbs free energy of the reaction $[20,52]$ :

$\Delta G_{F}=-n F E$

Eq. 5

Where $E=E_{r, c}-E_{r, a}$ is the potential difference between cathodic potential $\left(E_{r, c}\right)$ of Eq. 3 and anodic potential $\left(E_{r, a}\right)$ of Eq. $2 ; F$ is the Faraday constant; $n$ is the number of exchanged electrons.

According to Eq. 5, the more positive $E$, the more negative the $\Delta G_{F}$. If $\Delta G_{F}$ is negative, the chemical reaction will be spontaneous. A more negative value of $\Delta G_{F}$ represents stronger driving force of the reaction.

Since most of the reactions happen in a non-standard condition, the electrode potential varies according to the experimental conditions. Based on the oxidation and reduction reactions described in Eqs. 2 and 3, as well as the total reaction described in Eq. 4, the half-cell real electrode potential of oxidation-reduction reaction can be calculated according to the Nernst equation, shown in the following Eqs. 6-7 [20]:

$E_{r, a}^{r}=E_{r, a}^{0}+\frac{R T}{n F} \ln \left(\frac{\mathrm{a}_{\mathrm{M}} \mathrm{m}+}{\mathrm{C}_{\mathrm{M}}}\right)^{\frac{\mathrm{n}}{\mathrm{m}}}$

Eq. 6

$E_{r, c}^{r}=E_{r, c}^{0}+\frac{R T}{n F} \ln \left(\frac{\mathrm{a}_{0 x}}{\mathrm{a}_{\text {Red }}}\right)$

where $E^{r}$ is the real electrode potential; $R$ is the gas constant; $\mathrm{a}_{\mathrm{M}^{\mathrm{m+}}}, \mathrm{a}_{\mathrm{Ox}}$ and $\mathrm{a}_{\mathrm{Red}}$ are the activities of the reaction species in the melt, which are the product of the concentration and activity coefficient; $\mathrm{C}_{\mathrm{M}}$ is the concentrations of the alloying element, which can be assumed unity for metals. 
In the following section, the corrosion mechanism of molten chloride salts in absence and presence of $\mathrm{Mg}$ inhibitor will be discussed based on the above described oxidation-reduction reactions.

\subsubsection{Corrosion in molten chloride salts without Mg addition}

Corrosion tests results from Ambroseck et.al (2010) [9] and Wang et.al (2017) [23] have indicated that addition of $\mathrm{MgCl}_{2}$ in $\mathrm{KCl}-\mathrm{MgCl}_{2}$ salts will accelerate the corrosion of alloys because of the increased concentration of corrosive impurities. Due to the strong hygroscopicity, covalent metal halides (e.g., $\mathrm{MgCl}_{2}, \mathrm{CaCl}_{2}$ ) are easily hydrated when in contact with air or moisture. Consequently, oxidizing corrosive impurities (e.g., hydroxide species, $\mathrm{HCl}$ ) are produced from the hydrated salts during the heating-up procedure [9,18,26]. In addition, molecular $\mathrm{O}_{2}$ can react with $\mathrm{Cl}^{-}$to form corrosive $\mathrm{O}^{2-}$ and $\mathrm{Cl}_{2}$. This corrosion phenomenon is consistent with the corrosion thermodynamics. According to Eq. 7, the increased concentration of corrosive impurities in the melt can increase $E_{r, c}^{r}$. Thus, the Gibbs free energy of formation $\left(\Delta G_{F}\right)$ for the corrosion reaction in Eq. 5 will be more negative, i.e., stronger driving force of the corrosion reaction. Eqs. 8-10 and Fig. 21 describe the chemical reactions presumably producing the corrosive species in the molten salt.

$$
\begin{array}{lr}
\mathrm{MgCl}_{2}+\mathrm{H}_{2} \mathrm{O} \text { (hydrated) } \rightarrow \mathrm{MgOHCl}+\mathrm{HCl}(\mathrm{g}) & \text { Eq. } 8 \\
\mathrm{MgOHCl}(\mathrm{s}) \rightarrow \mathrm{MgOH}^{+}+\mathrm{Cl}^{-} & \text {Eq. } 9 \\
\mathrm{O}_{2}+4 \mathrm{Cl}^{-} \rightarrow 2 \mathrm{O}^{2-}+2 \mathrm{Cl}_{2}(\mathrm{~g}) & \text { Eq. } 10
\end{array}
$$

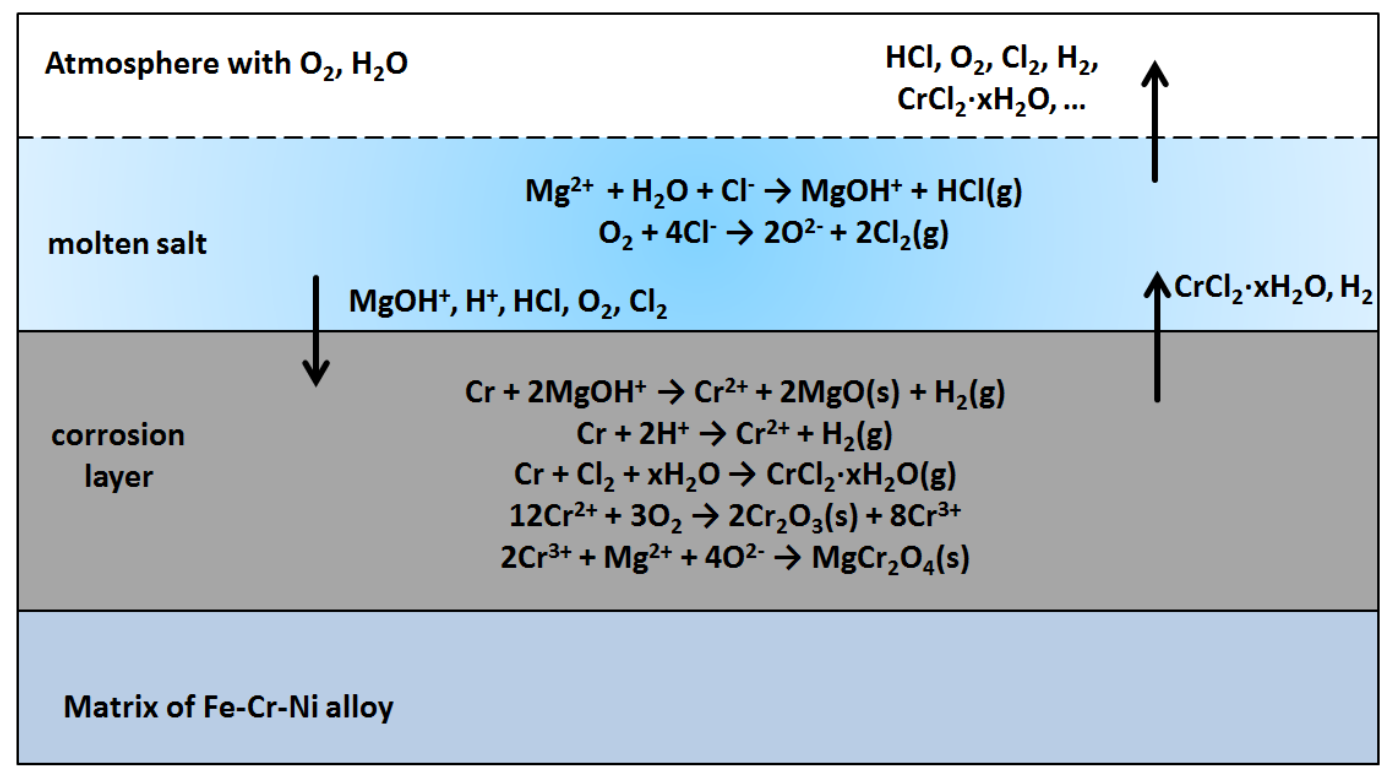


Fig. 21 Hypothetical corrosion mechanism of Fe-Ni-Cr based alloys in molten $\mathrm{MgCl}_{2} / \mathrm{KCl} / \mathrm{NaCl}$ without $\mathrm{Mg}$ corrosion inhibitor, adopted from previous work [21].

Chromium alloying will not only help improve the mechanical properties of commercial high temperature alloys, but also promote the formation of protective passive oxide scales as a barrier in oxidizing environment [45-46,56-57]. However, various experimental results have indicated that that $\mathrm{Cr}$-alloying steels will not form a protective $\mathrm{Cr}_{2} \mathrm{O}_{3}$ scale in molten chloride salts because of the high dissolution of $\mathrm{Cr}$-oxides in molten chloride salts [30,41]. Even $\mathrm{Cr}_{2} \mathrm{O}_{3}$ itself is prone to dissolve as $\mathrm{CrO}_{4}{ }^{2-}[32,42]$. Our previous work [21] showed that $\mathrm{Cr}$ is the most active element in the Fe-Cr-Ni alloys to be reduced in the anode, followed by $\mathrm{Fe}$, and $\mathrm{Ni}$ is noble. The standard electromotive forces (EMF) shown in Table 1 represent standard reduction potentials of the alloying elements in their chloride salts. As $\mathrm{Cr}$ has a higher EMF value (i.e., more negative $E_{r, a}$ ) than $\mathrm{Fe}$ and $\mathrm{Ni}$, Cr will be preferentially oxidized in the $\mathrm{Fe}-\mathrm{Cr}-\mathrm{Ni}$ alloy system, according the corrosion thermodynamics. $\mathrm{CrCl}_{2}$ and $\mathrm{FeCl}_{2}$ will form which have a high solubility in molten chloride salts will leave sample surface. Fig. 21 shows the schematic diagram of the corrosion mechanism of Fe-Ni-Cr based alloys in molten $\mathrm{MgCl}_{2} / \mathrm{KCl} / \mathrm{NaCl}$ without $\mathrm{Mg}$ corrosion inhibitor. The reactions between $\mathrm{Cr}$ and the corrosion impurities $\mathrm{MgOH}^{+}, \mathrm{O}_{2}, \mathrm{Cl}_{2}, \mathrm{HCl}$ in the corrosion layer in Fig. 21 are shown in Eqs. 11-15 [18,21]. The corrosion products can be the gaseous hydrated $\mathrm{Cr}$-chlorides such as $\mathrm{CrCl}_{2} \cdot \mathrm{xH}_{2} \mathrm{O}$ [59] and $\mathrm{Mg}-\mathrm{Cr}$ oxide precipitates like $\mathrm{MgCr}_{2} \mathrm{O}_{4}$ which have been found in previous work [21].

$$
\begin{array}{lr}
\mathrm{Cr}+2 \mathrm{MgOH}^{+} \rightarrow \mathrm{Cr}^{2+}+2 \mathrm{MgO}(\mathrm{s})+\mathrm{H}_{2}(\mathrm{~g}) & \text { Eq. } 11 \\
\mathrm{Cr}+2 \mathrm{H}^{+} \rightarrow \mathrm{Cr}^{2+}+\mathrm{H}_{2}(\mathrm{~g}) & \text { Eq. } 12 \\
\mathrm{Cr}+\mathrm{Cl}_{2}+\mathrm{xH}_{2} \mathrm{O} \rightarrow \mathrm{CrCl}_{2} \cdot \times \mathrm{H}_{2} \mathrm{O}(\mathrm{g}) & \text { Eq. } 13 \\
12 \mathrm{Cr}^{2+}+3 \mathrm{O}_{2} \rightarrow 2 \mathrm{Cr}_{2} \mathrm{O}_{3}(\mathrm{~s})+8 \mathrm{Cr}^{3+} & \text { Eq. } 14 \\
2 \mathrm{Cr}^{3+}+\mathrm{Mg}^{2+}+4 \mathrm{O}^{2-} \rightarrow \mathrm{MgCr}_{2} \mathrm{O}_{4}(\mathrm{~s}) & \text { Eq. } 15
\end{array}
$$

\subsubsection{Effects of $\mathrm{Mg}$ addition}

In order to understand the effects of $\mathrm{Mg}$ addition, the thermodynamics of the corrosion of alloys in molten chlorides is considered. Corrosion can be caused by any agent (e.g., $\mathrm{H}^{+}, \mathrm{MgOH}^{+}$) that controls the redox potential. For simplicity, $\mathrm{HCl}(\mathrm{I}) / \mathrm{H}_{2}$ is considered here. According to the reaction below: 


$$
\frac{1}{2} \mathrm{H}_{2}(\mathrm{~g})+\frac{1}{2} \mathrm{Cl}(\mathrm{g})=\mathrm{HCl}(\mathrm{l}), \quad \Delta G_{H C l}^{0}
$$

the redox potential of the molten chloride (i.e., chlorine potentials $\Delta G_{C_{2}}$ ) can be defined as the redox potential of the molten fluoride (i.e., fluorine potentials $\Delta G_{F_{2}}$ ) in [37]:

$\Delta G_{C l_{2}} \stackrel{\text { def }}{=} R T \ln p_{C l_{2}}=2 R T \ln \left(a_{H C l} / \sqrt{p_{H_{2}}}\right)+2 \Delta G_{H C l}^{0}$,

since the standard free energy of formation of Eq. 16 is

$$
\Delta G_{H C l}^{0}=-R T \ln K=-R T \ln \left(\frac{a_{\mathrm{HCl}}}{\sqrt{p_{\mathrm{H}_{2}}} \sqrt{p_{\mathrm{Cl}_{2}}}}\right),
$$

where $K$ is the equilibrium constant of the reaction in Eq. 16 , and $a_{\mathrm{HCl}}$ is the activity of $\mathrm{HCl}$ in molten chlorides, $p_{\mathrm{H}_{2}}$ and $p_{\mathrm{Cl}_{2}}$ is the partial pressure of $\mathrm{H}_{2}$ and $\mathrm{Cl}_{2}$, respectively. The activity is a product of the molar fraction and the activity coefficient of this component.

The corrosion reaction of the alloys in molten chlorides (e.g., dissolution of $\mathrm{Cr}$ ) is:

$$
\mathrm{Cr}(\mathrm{s})+2 \mathrm{HCl}(\mathrm{l})=\mathrm{CrCl}_{2}(\mathrm{l})+\mathrm{H}_{2}(\mathrm{~g}), \quad \Delta G_{\mathrm{CrCl}_{2}}^{0}
$$

with the equilibrium expression of:

$$
\frac{p_{\mathrm{H}_{2}} a_{\mathrm{CrCl}_{2}}}{a^{2}{ }_{\mathrm{HCl}}}=\exp \left(-\frac{\Delta G_{\mathrm{CrCl}}^{0}-2 \Delta G_{\mathrm{HCl}}^{0}}{R T}\right),
$$

where $\Delta G_{\mathrm{CrCl}_{2}}^{0}$ is the standard free energy of formation of pure $\mathrm{CrCl}_{2}$ liquid (at $800^{\circ} \mathrm{C}, \Delta G_{\mathrm{CrCl}_{2}}^{0}=$ $-261 \mathrm{~kJ} / \mathrm{mol}$ ), and $a_{\mathrm{CrCl}_{2}}$ is the activity of $\mathrm{CrCl}_{2}$ in molten chlorides. Using Eq. 17 to eliminate the partial pressures of $\mathrm{H}_{2}$ and $\mathrm{HCl}$ yields

$$
R T \ln \left(a_{C r C l_{2}}\right)=\Delta G_{C l_{2}}-\Delta G_{C r C l_{2}}^{0} .
$$

Thus, the lower the redox potential $\Delta G_{C l_{2}}$, the lower equilibrium concentration the $\mathrm{CrCl}_{2}$ in the molten chloride has.

Addition of the metals (e.g., $\mathrm{Mg}$ ) to the molten chlorides can reduce the redox potentials (i.e., chlorine potential $\left.\Delta G_{C l_{2}}\right)$. For $\mathrm{Mg}$, the formation reaction of $\mathrm{MgCl}_{2}$ is

$$
\mathrm{Mg}(\mathrm{s})+\mathrm{Cl}_{2}(\mathrm{~g})=\mathrm{MgCl}_{2}(\mathrm{l}), \quad \Delta G_{M g C l_{2}}^{0}
$$

with the equilibrium expression of: 


$$
\frac{a_{M C_{2}}}{p_{C l_{2}}}=\exp \left(-\frac{\Delta G_{M g C l_{2}}^{0}}{R T}\right),
$$

Where $\Delta G_{M g C l}$ is the standard free energy of formation of pure $\mathrm{MgCl}_{2}$ liquid (at $800^{\circ} \mathrm{C}$, $\Delta G_{M C l_{2}}^{0}=-475 \mathrm{~kJ} / \mathrm{mol}$ [52]), and $a_{\mathrm{MgCl}_{2}}$ is the activity of $\mathrm{MgCl}_{2}$ in molten chlorides. Therefore, the redox potential of the molten chloride $\Delta G_{\mathrm{Cl}_{2}}$ is reduced by adding $\mathrm{Mg}$ :

$$
\Delta G_{C l_{2}} \stackrel{\text { def }}{=} R T \ln p_{C l_{2}}=R T \ln \left(a_{M g C l_{2}}\right)+\Delta G_{M g C l_{2}}^{0}
$$

Substituting the redox potential of the molten chloride $\Delta G_{\mathrm{Cl}_{2}}$ in Eq. 24 into Eq. 21 yeilds

$$
\begin{gathered}
R T \ln \left(a_{\mathrm{CrCl}_{2}}\right)=R T \ln \left(a_{\mathrm{MgCl}_{2}}\right)+\Delta G_{\mathrm{MgCl}_{2}}^{0}-\Delta G_{\mathrm{CrCl}_{2}}^{0}, \\
\rightarrow a_{\mathrm{CrCl}_{2}}=a_{\mathrm{MgCl}_{2}} \cdot \operatorname{Exp}\left(\frac{\Delta G_{\mathrm{MgCl}_{2}}^{0}-\Delta G_{\mathrm{CrCl}_{2}}^{0}}{R T}\right) .
\end{gathered}
$$

For $\mathrm{FeCl}_{2}$ and $\mathrm{NiCl}_{2}$, the equations are:

$$
\begin{gathered}
a_{\mathrm{FeCl}_{2}}=a_{\mathrm{MgCl}_{2}} \cdot \operatorname{Exp}\left(\frac{\Delta G_{\mathrm{MgCl}_{2}}^{0}-\Delta G_{\mathrm{FeCl}_{2}}^{0}}{R T}\right) . \\
\rightarrow a_{\mathrm{NiCl}_{2}}=a_{\mathrm{MgCl}_{2}} \cdot \operatorname{Exp}\left(\frac{\Delta G_{\mathrm{MgCl}}^{0}-\Delta G_{\mathrm{NiCl}_{2}}^{0}}{R T}\right) .
\end{gathered}
$$

From Eqs. 25-27, the equilibrium molar fractions of $\mathrm{CrCl}_{2}, \mathrm{FeCl}_{2}$ and $\mathrm{NiCl}_{2}$ in $\mathrm{MgCl}_{2}-\mathrm{KCl}-\mathrm{NaCl}$ (60-20-20 mole \%) with Mg addition can be calculated, using the standard free energy of formation of $\mathrm{MgCl}_{2}(-475 \mathrm{~kJ} / \mathrm{mol}), \mathrm{CrCl}_{2}, \mathrm{FeCl}_{2}$ and $\mathrm{NiCl}_{2}$ (see Table 1). Under the assumption that the activity coefficients of $\mathrm{MgCl}_{2}, \mathrm{CrCl}_{2}, \mathrm{FeCl}_{2}$ and $\mathrm{NiCl}_{2}$ in the melt are the same and equal to 0.1 [37], the redox potential of the $\mathrm{MgCl}_{2}-\mathrm{KCl}-\mathrm{NaCl}(60-20-20$ mole \%) with $\mathrm{Mg}$ addition at $800^{\circ} \mathrm{C}$ as well as the equilibrium molar fractions of $\mathrm{CrCl}_{2}, \mathrm{FeCl}_{2}$ and $\mathrm{NiCl}_{2}$ in the melt are calculated and presented in Table 6.

Table 6 Calculated redox potential of $\mathrm{MgCl}_{2}-\mathrm{KCl}-\mathrm{NaCl}\left(60-20-20\right.$ mole \%) with $\mathrm{Mg}$ addition at $800^{\circ} \mathrm{C}$, and calculated equilibrium molar fractions of $\mathrm{CrCl}_{2}, \mathrm{FeCl}_{2}$ and $\mathrm{NiCl}_{2}$ in the melt.

\begin{tabular}{llllll}
\hline $\mathrm{T}\left({ }^{\circ} \mathrm{C}\right)$ & Redox potential $\Delta \boldsymbol{G}_{\mathrm{Cl}_{2}}$ & $\mathrm{Mg}^{2+}(\mathrm{mol} \%)$ & $\mathrm{Cr}^{2+}(\mathrm{mol} \%)$ & $\mathrm{Fe}^{2+}(\mathrm{mol} \%)$ & $\mathrm{Ni}^{2+}\left(\mathrm{mol}^{2+}\right)$ \\
& with $\mathrm{Mg}(\mathrm{kJ} / \mathrm{mol})$ & & & & \\
\hline 800 & -500 & 0.6 & $2.3 \times 10^{-11}$ & $1.5 \times 10^{-13}$ & $8.5 \times 10^{-16}$ \\
\hline
\end{tabular}

In equilibrium, the molar fraction of $\mathrm{Mg}^{2+}$ in the melt is much higher than that of $\mathrm{Cr}^{2+}, \mathrm{Fe}^{2+} \mathrm{or} \mathrm{Ni}^{2+}$. Thus, Mg reacts preferentially with the oxidizing impurities in the melt than $\mathrm{Cr}$, $\mathrm{Fe}$ and $\mathrm{Ni}$, when exposure of $\mathrm{Fe}-\mathrm{Ni}-\mathrm{Cr}$ alloys in molten $\mathrm{MgCl}_{2}-\mathrm{KCl}-\mathrm{NaCl}$ with $\mathrm{Mg}$ addition. Fig. 22 shows the 
schematic diagram of the corrosion mitigation mechanism of $\mathrm{Fe}-\mathrm{Ni}-\mathrm{Cr}$ based alloys in molten $\mathrm{MgCl}_{2} / \mathrm{KCl} / \mathrm{NaCl}$ with $\mathrm{Mg}$ corrosion inhibitor. The following reactions (Eqs. 28-32) are assumed to describe the interactions between $\mathrm{Mg}$ metal and corrosive impurities in the molten salts.

$\mathrm{Mg}+2 \mathrm{MgOH}^{+} \rightarrow \mathrm{Mg}^{2+}+2 \mathrm{MgO}(\mathrm{s})+\mathrm{H}_{2}(\mathrm{~g}) \quad$ Eq. 28

$\mathrm{Mg}+2 \mathrm{H}^{+} \rightarrow \mathrm{Mg}^{2+}+\mathrm{H}_{2}(\mathrm{~g})$

$\mathrm{Mg}+\mathrm{Cl}_{2} \rightarrow \mathrm{Mg}^{2+}+2 \mathrm{Cl}^{-}$

Eq. 30

$\mathrm{Mg}^{2+}+\mathrm{O}^{2-} \rightarrow \mathrm{MgO}(\mathrm{s})$

Eq. 31

$2 \mathrm{Mg}+\mathrm{O}_{2} \rightarrow 2 \mathrm{MgO}(\mathrm{s})$

Eq. 32

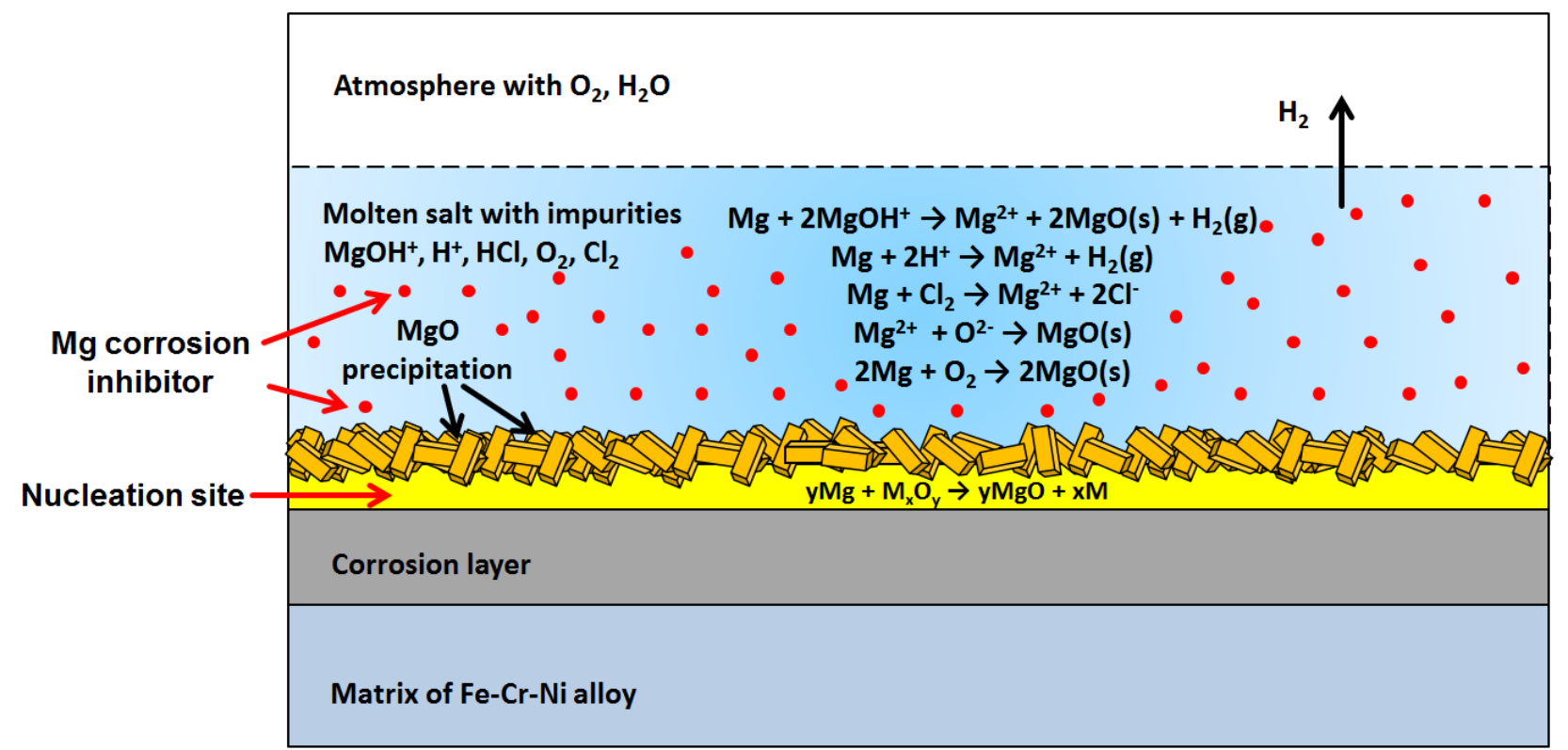

Fig. 22 Corrosion mitigation mechanism of $\mathrm{Fe}-\mathrm{Ni}-\mathrm{Cr}$ alloys in molten $\mathrm{MgCl}_{2} / \mathrm{KCl} / \mathrm{NaCl}$ with $\mathrm{Mg}$ corrosion inhibitor.

A considerable amount of $\mathrm{MgO}$ is produced, as evidenced by the SEM/EDS analysis shown earlier. Since $\mathrm{MgO}$ has a low solubility in molten chloride salts (solubility in $\mathrm{MgCl}_{2}-\mathrm{NaCl}$ : $4.6 \times 10^{-}$ ${ }^{3} \mathrm{~mol} / \mathrm{kg}$ (salt) at $\left.730^{\circ} \mathrm{C}[50,60]\right)$, its precipitation leads to the observed thick and dense $\mathrm{MgO}$ layers, which cover the alloy surfaces. We assume that this layer acts as a diffusion barrier. Regarding the growth of $\mathrm{MgO}$ layer on the metal surface, we assume that $\mathrm{Mg}$ dissolved in the molten salts will react with initial $\mathrm{Cr}-$, $\mathrm{Fe}$ - and $\mathrm{Ni}$-based oxides according to the Ellingham diagrams [61] and Eq. 33. Subsequently, the formed MgO will precipitate on metal surface (as schematically shown Fig. 22). 
$y M g+M_{x} O_{y} \rightarrow y M g O+x M$,

Eq. 33

Where $\mathrm{M}$ is $\mathrm{Cr}, \mathrm{Fe}, \mathrm{Ni}$.

Besides, this solid metal-liquid salt-interface will provide a nucleation site for $\mathrm{MgO}$ (see Fig. 22). On the one hand, this thick $\mathrm{MgO}$ scale might prevent diffusion, thereafter lowering the corrosion rates of structural materials. On the other hand, the thick $\mathrm{MgO}$ scales might impact the thermal performance of the system, causing challenges for the engineering design of the main components, like the heat exchanger and the receiver. Therefore, the corrosion of structural materials caused by molten chloride salts could be mitigated by applying an approach in which salt purification techniques should be combined with an optimized Mg-metal addition.

Although the corrosion layers are reduced, compared with the experiments performed without $\mathrm{Mg}$ addition, there are still corrosion attacks detected on all test alloys. This may be explained by the fact that at the beginning of the exposure test, $\mathrm{Mg}$ metal needs time to dissolve and react with impurities. Therefore, the corrosion at the alloy surface may happen due to the high concentrations of corrosive impurities at the initial stage. In a closed system, the concentrations (i.e., activities) of oxidants (impurities) will be decreased after reacting with $\mathrm{Mg}$. Then, the corrosion of alloys will slow down or even stop, as well as the growth of the MgO scale, when the corrosive impurities are totally consumed.

\subsection{Corrosion of pre-oxidized alumina forming Fe-Cr-Al alloys}

Both of the pre-oxidized alumina forming $\mathrm{Fe}-\mathrm{Cr}$-Al alloys show corrosion resistance towards the molten chloride salts in the $500 \mathrm{~h}$ isothermal test at $700^{\circ} \mathrm{C}$ under inert atmosphere. No depletion of $\mathrm{Cr}$ in the matrix is visible. After $500 \mathrm{~h}$ exposure to molten salts at $700^{\circ} \mathrm{C}$, only $\alpha-\mathrm{Al}_{2} \mathrm{O}_{3}$ and $\mathrm{MgO}$ phases are detected in the oxide scales, as shown in Fig. 15. Our results indicate that preoxidized $\mathrm{Al}_{2} \mathrm{O}_{3}$ scale can effectively mitigate the hot corrosion of structural alloys in molten chloride salts at $700^{\circ} \mathrm{C}$ under inert atmosphere.

Compared with a chromia layer, the dense $\alpha-\mathrm{Al}_{2} \mathrm{O}_{3}$ scale is more protective at high temperature because it is thermodynamically stable and slowly growing over time [56,62]. In the molten chloride salts, $\mathrm{Al}_{2} \mathrm{O}_{3}$ is stable and inert to the corrosive impurities [42,63], while $\mathrm{Cr}_{2} \mathrm{O}_{3}$ is easily dissolved as Chromate ion $\left(\mathrm{CrO}_{4}{ }^{2-}\right)$ [32,42]. Results from Pan et.al (2011) [64] and Li et.al (2007) 
[42] show that the chlorine partial pressure produced by Eq. 34 is $10^{-15} \mathrm{~atm}$ in comparison to $10^{-}$ ${ }^{5}$ atm produced by chromia, indicating the stability of $\mathrm{Al}_{2} \mathrm{O}_{3}$ in chloride environments.

$2 \mathrm{KCl}(\mathrm{s}, \mathrm{L})+\mathrm{Al}_{2} \mathrm{O}_{3}(\mathrm{~s})+1 / 2 \mathrm{O}_{2}(\mathrm{~g})=2 \mathrm{KAIO}_{2}(\mathrm{~s})+\mathrm{Cl}_{2}(\mathrm{~g})$

The protective $\mathrm{Al}_{2} \mathrm{O}_{3}$ scales show strong adherence to the base materials in case of both alloys. It has also been demonstrated elsewhere that, like in this study, some elements (like $\mathrm{Y}, \mathrm{Zr}, \mathrm{Hf}$ ) can improve the adherence of the scales significantly [53,62].

Both model alloys show a tremendous increase in thickness of the oxide scale after exposure to molten salts from $\sim 1 \mu \mathrm{m}$ to $\sim 9 \mu \mathrm{m}$. The growth of the alumina layer which requires oxygen, is an indication of the oxygen species' presence in the molten salt. Therefore, any oxidizing species in the chloride salts should be reduced prior of their use, by purification techniques, in order to reduce the corrosion of the structural materials and the growth rate of the oxide scale on their surface during exposure.

\section{Conclusions}

Based on the results, the main conclusions are:

(1) After $500 \mathrm{~h}$ exposure at $700^{\circ} \mathrm{C}$ in molten $\mathrm{MgCl}_{2}-\mathrm{KCl}-\mathrm{NaCl}$ salts with $\mathrm{Mg}$ addition under inert atmosphere, the measured corrosion depths of SS $310, \ln 800 \mathrm{H}$ and Hastelloy C-276 are 17 \pm 4 , $15 \pm 3$ and $1.7 \pm 0.5 \mu \mathrm{m}$, respectively. The calculated corrosion rate of SS $310, \ln 800 \mathrm{H}$ and $\mathrm{Ha}$ C-276 is $298 \pm 70,262 \pm 52$, and $29.8 \pm 8.7 \mu \mathrm{m} /$ year, respectively. Hastelloy C-276 shows the best corrosion resistance, and approaches the demands for commercial applications as structural materials $(<15 \mu \mathrm{m} /$ year $)$.

(2) Adding $\mathrm{Mg}$ (1 wt.-\% Mg) as corrosion inhibitor in chloride salts can significantly reduce the corrosion rate in case of Fe-Cr-Ni based alloys. The corrosion rate can be reduced by $\sim 83 \%$ for SS $310, \sim 70 \%$ for In $800 \mathrm{H}$ and $\sim 94 \%$ for Ha C-276 compared with the exposure tests without Mg addition.

(3) The degradation of Fe-Cr-Ni based alloys in molten chloride salts is considered as impuritydriven corrosion. According to the corrosion thermodynamics of alloys in molten chlorides with $\mathrm{Mg}$ addition, $\mathrm{Mg}$ preferentially reacts with the impurities in the salts until either $\mathrm{Mg}$ or the impurities are consumed. The formed $\mathrm{MgO}$ layer on the alloy surface might act as a barrier to inhibit direct contact between salts and metals. However, the formation, the growth, the compactness and the influence on the corrosion process of the $\mathrm{MgO}$ deposit should be future explored during long term experiments. 
(4) The alumina scale obtained by pre-oxidizing the Fe-Cr-Al alloys is corrosion resistant to the molten chloride salts when exposed at $700^{\circ} \mathrm{C}$ for $500 \mathrm{~h}$ under inert atmosphere. It can effectively prevent the diffusion of $\mathrm{Cr}$ into the salt and the penetration of corrosive impurities into the alloy. Moreover, it shows strong adherence on the alloy substrates.

(5) After $500 \mathrm{~h}$ exposure to molten salts at $700^{\circ} \mathrm{C}$, only stable $\alpha-\mathrm{Al}_{2} \mathrm{O}_{3}$ phase is detected in the oxide scale. Long term experiments performed in molten chloride salts with improved purity are required to monitor the alumina growth rate and stability.

(6) We present results on two promising approaches to minimize corrosion rates of structural materials in contact with molten chlorides for next generation thermal energy storage and heat transfer fluid application in concentrating solar power plants (see Fig. 23). This progress on material aspects will support the development of molten chloride salt technology.

\section{Corrosion mitigation strategies for molten chlorides in next generation CSP plants}

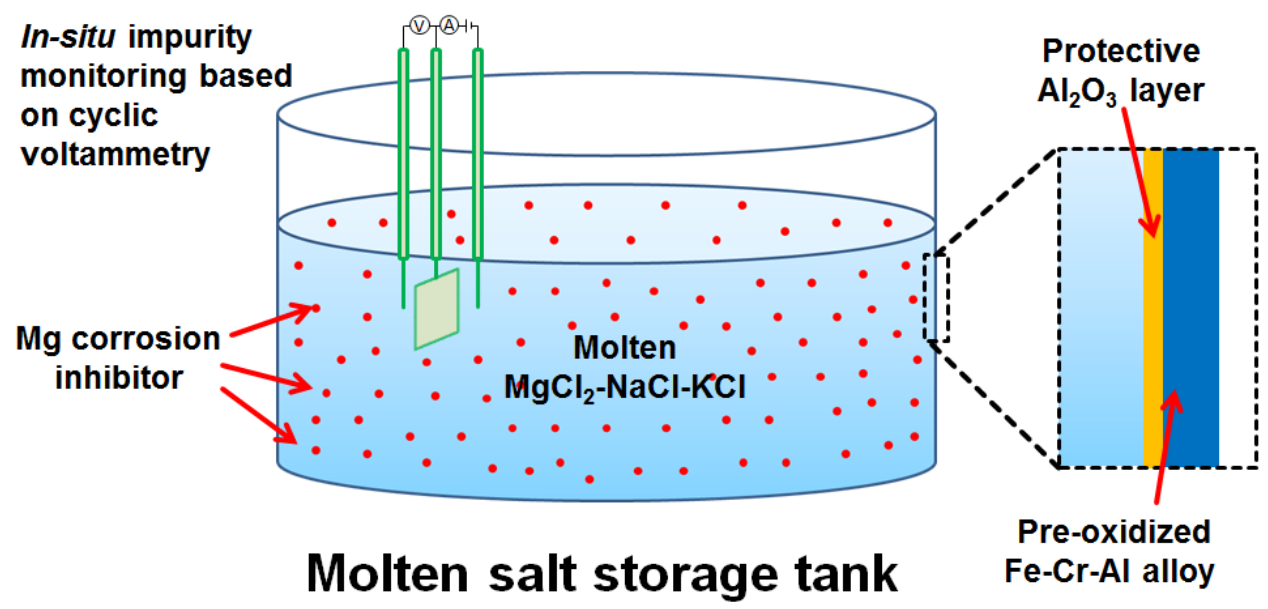

Fig. 23 Corrosion mitigation strategies for structural materials in molten chlorides for next generation CSP plants under in-situ impurity monitoring based on cyclic voltammetry (CV): a) active metal corrosion inhibitor, b) alumina forming Al-containing alloys.

\section{Acknowledge}

W. Ding and H. Shi contributed equally to this work. This research has been performed within the DLR-DAAD fellowship program (Grant number 57265854), which is funded by German Academic Exchange Service (DAAD) and German Aerospace Center (DLR). H. Shi appreciates the PhD fellowship funded by the China Scholarship Council (CSC). The authors would like to 
thank Markus Braun and Jochen Forstner at the DLR-Institute of Engineering Thermodynamics for their technical support.

\section{Reference}

1. P. D. Myers and D. Y. Goswami, Thermal energy storage using chloride salts and their eutectics, Appl. Therm. Eng. 109 (2016) 889-900.

2. A. Bonk, S. Sau, N. Uranga, M. Hernaiz and T. Bauer, Advanced heat transfer fluids for direct molten salt line-focusing CSP plants, Prog. Energy Combust. Sci. 67 (2018) 69-87.

3. A. Henry and R. Prasher, The prospect of high temperature solid state energy conversion to reduce the cost of concentrated solar power, Energy Environ. Sci. 7 (2014) 1819-1828.

4. K. Vignarooban, X. Xu, A. Arvay, K. Hsu and A. M. Kannan, Heat transfer fluids for concentrating solar power systems-a review, Appl. Energy 146 (2015) 383-396.

5. M. Roeb, M. Neises, N. Monnerie, C. Sattler, R. Pitz-Paal, Technologies and trends in solar power and fuels, Energy Environ. Sci. 4 (2011) 2503-2511.

6. B. Coelho, A. C. Oliveira and A. Mendes, Concentrated solar power for renewable electricity and hydrogen productionfrom water - a review, Energy Environ. Sci. 3 (2010) 1398-1405.

7. D. Kearney, U. Herrmann, P. Nava, B. Kelly, R. Mahoney, J. Pacheco, R. Cable, D. Blake and $\mathrm{H}$. Price, Assessment of a molten salt heat transfer fluid in a parabolic trough solar field, J. Sol. Energy Eng. 125(2) (2003) 170-176.

8. M. Liu, W. Saman, and F. Bruno, Review on storage materials and thermal performance enhancement techniques for high temperature phase change thermal storage systems, Renewable Sustainable Energy Rev. 16(4) (2012) 2118-2132.

9. J. W. Ambrosek, Thesis (Ph.D.): Molten chloride salts for heat transfer in nuclear systems, Publication Number: AAT 3471128; ISBN: 9781124822778; Advisor: Allen, Todd R, 2011.

10. M. S. Sohal, M. A. Ebner, P. Sabharwall, and P. Sharpe, Engineering database of liquid salt thermos-physical and thermochemical properties, Idaho National Laboratory (INL), No. INL/EXT-10-18297, 2010.

11. U. Herrmann, B. Kelly, and H. Price, Two-tank molten salt storage for parabolic trough solar power plants, Energy 29(5-6) (2004) 883-893.

12. N. S. Patel, V. Pavlík, and M. Boča, High-temperature corrosion behavior of superalloys in molten salts - a review, Crit. Rev. Solid State Mater. Sci. 42(1) (2017) 83-97. 
13. G. Alva, L. Liu, X. Huang, and G. Fang, Thermal energy storage materials and systems for solar energy applications, Renewable Sustainable Energy Rev. 68 (2017) 693-706.

14. K. Niedermeier, J. Flesch, L. Marocco, and T. Wetzel, Assessment of thermal energy storage options in a sodium-based CSP plant, Appl. Therm. Eng. 107 (2016) 386-397.

15. T. Bauer, N. Pfleger, D. Laing and S. Kaesche, High-temperature molten salts for solar power application, Chapter 20 in book: molten salts chemistry, p. 415, ISBN: 978-0-12398538-5, 2013.

16. K. Vignarooban, P. Pugazhendhi, C. Tucker, D. Gervasio and A. M. Kannan, Corrosion resistance of Hastelloys in molten metal-chloride heat-transfer fluids for concentrating solar power applications, Sol. Energy 103 (2014) 62-69.

17. J. Gasia, L. Miró and L. F. Cabeza, Review on system and materials requirements for high temperature thermal energy storage. Part 1: General requirements, Renewable Sustainable Energy Rev. 75 (2017) 1320-1338.

18. W. Ding, A. Bonk and T. Bauer, Corrosion behavior of metallic alloys in molten chloride salts for thermal energy storage in concentrated solar power plants - A review, Front. Chem. Sci. Eng. 2018 accepted. https://doi.org/10.1007/s11705-018-1720-0.

19. M. Mehos, C. Turchi, J. Vidal, M. Wagner, Z. Ma, C. Ho, W. Kolb, C. Andraka and A. Kruizenga, Concentrating solar power Gen3 demonstration roadmap. Technical Report: NREL/TP-5500-67464, National Renewable Energy Laboratory, Golden, CO, 2017.

20. S. Guo, J. Zhang, W. Wu and W. Zhou, Corrosion in the molten fluoride and chloride salts and materials development for nuclear applications, Prog. Mater. Sci. 97 (2018) 448-487.

21. W. Ding, H. Shi, Y. Xiu, A. Bonk, A. Weisenburger, A. Jianu and T. Bauer, Hot corrosion behavior of commercial alloys in thermal energy storage material of molten $\mathrm{MgCl}_{2} / \mathrm{KCl} / \mathrm{NaCl}$ under inert atmosphere, Sol. Energy Mater. Sol. Cells 184 (2018) 22-30.

22. Y. Li, X. Xu, X. Wang, P. Li, Q. Hao and B. Xiao, Survey and evaluation of equations for thermos-physical properties of binary/ternary eutectic salts from $\mathrm{NaCl}, \mathrm{KCl}, \mathrm{MgCl}_{2}, \mathrm{CaCl}_{2}$, $\mathrm{ZnCl}_{2}$ for heat transfer and thermal storage fluids in CSP, Sol. Energy 152 (2017) 57-79.

23. K. Sridharan, T.R. Allen, Corrosion in molten salts. Chapter 12 in book: Molten Salts Chemistry. Elsevier 2013. p. 241-267.

24. J. W. Wang, H. X. Zhou, C. Z. Zhang, W. N. Liu and B. Y. Zhao, Influence of $\mathrm{MgCl}_{2}$ content on corrosion behavior of $\mathrm{GH} 1140$ in molten $\mathrm{NaCl}-\mathrm{MgCl}_{2}$ as thermal storage medium, Sol. Energy Mater. Sol. Cells 179 (2017) 194-201. 
25. J.C. Gomez-Vidal, R. Tirawat, Corrosion of alloys in a chloride molten salt (NaCl-LiCl) for solar thermal technologies, Sol. Energy Mater. Sol. Cells 157 (2016) 234-244.

26. M. Zhu, H. Ma, M. Wang, Z. Wang and A. Sharif, Effects of Cations on Corrosion of Inconel 625 in Molten Chloride Salts, High Temp. Mater. Processes 35(4) (2016) 337345.

27. A. Nishikata, H. Numata, T. Tsuru, Electrochemistry of molten salt corrosion. Materials Science and Engineering: A 146 (1991) 15-31.

28. J.C. Gomez-Vidal, A.G. Fernandez, R. Tirawat, C. Turchi, W. Huddleston, Corrosion resistance of alumina forming alloys against molten chlorides for energy production. II: Electrochemical impedance spectroscopy under thermal cycling conditions. Sol. Energy Mater. Sol. Cells 166 (2017) 234-245.

29. K. Vignarooban, X. Xu, K. Wang, E.E. Molina, P. Li, D. Gervasio and A.M. Kannan, Vapor pressure and corrosivity of ternary metal-chloride molten-salt based heat transfer fluids for use in concentrating solar power systems, Appl. Energy 159 (2015) 206-213.

30. B. Liu, X. Wei, W. Wang, J. Lu and J. Ding, Corrosion behavior of Ni-based alloys in molten $\mathrm{NaCl}-\mathrm{CaCl}_{2}-\mathrm{MgCl}_{2}$ eutectic salt for concentrating solar power, Sol. Energy Mater. Sol. Cells 170 (2017) 77-86.

31. M. Anderson, K. Sridhara, T. Allen and P. Peterson, Liquid Salt Heat Exchanger Technology for VHTR Based Applications, Univ. of Wisconsin, Madison, WI (United States); Univ. of California at Berkeley, CA (United States); Battelle Energy Alliance, LLC, No. NEUP--Project-09-777, 2012.

32. A. Zahs, M. Spiegel and H. J. Grabke, Chloridation and oxidation of iron, chromium, nickel and their alloys in chloridizing and oxidizing atmospheres at 400-700 C, Corros. Sci. 42(6) (2000) 1093-1122.

33. C.G. Dariva, A.F. Galio, Corrosion inhibitors-principles, mechanisms and applications. In: Developments in corrosion protection. IntechOpen, 2014. DOI: 10.5772/57255.

34. J. E. Indacochea, J. L. Smith, K. R. Litko, E. J. Karell and A. G. Rarez, High-temperature oxidation and corrosion of structural materials in molten chlorides, Oxid. Met. 55(1-2) (2001) 1-16.

35. J. E. Indacochea, J. L. Smith, K. R. Litko and E. J. Karell, Corrosion performance of ferrous and refractory metals in molten salts under reducing conditions, J. Mater. Res. 14(5) (1999) 1990-1995. 
36. B. L. Garcia-Diaz, L. Olson, M. Martinez-Rodriguez, R. Fuentes, H. Colon-Mercado and J. Gray, High Temperature Electrochemical Engineering and Clean Energy Systems, Journal of the South Carolina Academy of Science 14(1) (2016) Article 4.

37. D. Olander, Redox condition in molten fluoride salts: Definition and control, J. Nucl. Mater. 300 (2002) 270-272.

38. M. Finsgar, J. Jackson, Application of corrosion inhibitors for steels in acidic media for the oil and gas industry: a review. Corr. Sci. 86 (2014) 17-41.

39. M. P. Brady, I. G. Wright, and B. Gleeson, Alloy design strategies for promoting protective oxide-scale formation, Jom 52(1) (2000) 16-21.

40. Y. Yamamoto, M. P. Brady, Z. P. Lu, P. J. Maziasz, C. T. Liu, B. A. Pint, K. L. More, H. M. Meyer and E. A. Payzant, Creep-resistant, $\mathrm{Al}_{2} \mathrm{O}_{3}$-forming austenitic stainless steels, Science 316 (2007) 433-436.

41. Y. S. Li, M. Spiegel and S. Shimada, Corrosion behaviour of various model alloys with $\mathrm{NaCl}-\mathrm{KCl}$ coating, Mater. Chem. Phys. 93(1) (2005) 217-223.

42. Y. S. Li, Y. Niu and M. Spiegel, High temperature interaction of Al/Si-modified $\mathrm{Fe}-\mathrm{Cr}$ alloys with $\mathrm{KCl}$, Corro. Sci. 49(4) (2007) 1799-1815.

43. A. M. Kruizenga, Corrosion mechanisms in chloride and carbonate salts, Sandia National Laboratories, Livermore, CA Report No. SAND2012-7594, 2012.

44. J. C. Gomez-Vidal, A. G. Fernandez, R. Tirawat, C. Turchi and W. Huddleston, Corrosion resistance of alumina-forming alloys against molten chlorides for energy production. I: Pre-oxidation treatment and isothermal corrosion tests, Sol. Energy Mater. Sol. Cells 166 (2017) 222-233.

45. Y. Yamamoto, G. Muralidharan and M. P. Brady, Development of L12-ordered Ni3 (Al, Ti)-strengthened alumina-forming austenitic stainless steel alloys, Scripta Mater. 69(1112) (2013) 816-819.

46. M. P. Brady, Y. Yamamoto, M. L. Santella, P. J. Maziasz, B. A. Pint, C. T. Liu, Z. P. Lu and $\mathrm{H}$. Bei, The development of alumina-forming austenitic stainless steels for hightemperature structural use, Jom 60(7) (2008) 12-18.

47. B. Jönsson, Q. Lu, D. Chandrasekaran, R. Berglund and F. Rave, Oxidation and creep limited lifetime of Kanthal APMT®, a dispersion strengthened FeCrAlMo alloy designed for strength and oxidation resistance at high temperatures, Oxid. Met. 79(1-2) (2013) 2939. 
48. M. Student, Y. Dzioba, V. Hvozdets'kyi, H. Pokhmurs'ka, B. Wielage and T. Grund, Hightemperature corrosion of electric-arc coatings sprayed from powder core wires based on the Fe-Cr-B-Al system, Mater. Sci. 44(5) (2008) 693-699.

49. J. K. Bunn, R. L. Fang, M. R. Albing, A. Mehta, M. J. Kramer, M. F. Besser and J. R. Hattrick-Simpers, A high-throughput investigation of $\mathrm{Fe}-\mathrm{Cr}-\mathrm{Al}$ as a novel hightemperature coating for nuclear cladding materials, Nanotechnology 26(27) (2015) 274003.

50. W. Ding, A. Bonk, J. Gussone and T. Bauer, Cyclic voltammetry for monitoring corrosive impurities in molten chlorides for thermal energy storage, Energy Procedia 135 (2017) 82-91.

51. W. Ding, A. Bonk, J. Gussone and T. Bauer, Electrochemical Measurement of Corrosive Impurities in Molten Chlorides for Thermal Energy Storage, J. Energ. Storage 15 (2018) 408-414.

52. W. J. Hamer, M. S. Malmberg and B. Rubin, Theoretical electromotive forces for cells containing a single solid or molten chloride electrolyte, J. Electrochem. Soc. 103(1) (1956) 8-16.

53. B. A. Pint, Optimization of Reactive-Element Additions to Improve Oxidation Performance of Alumina-Forming Alloys, J. Am. Ceram. Soc. 86(4) (2003) 686-95.

54. C. Issartel, H. Buscail, S. Chevalier and J. Favergeon, Effect of Yttrium as Alloying Element on a Model Alumina-Forming Alloy Oxidation at $1100^{\circ} \mathrm{C}$, Oxid. Met. $88(3-4)$ (2017) 409-420.

55. R. Prescott and M. J. Graham, The formation of aluminum oxide scales on hightemperature alloys, Oxid. Met. 38(3-4) (1992) 233-254.

56. Z. G. Zhang, F. Gesmundo, P. Y. Hou and Y. Niu, Criteria for the formation of protective $\mathrm{Al}_{2} \mathrm{O}_{3}$ scales on $\mathrm{Fe}-\mathrm{Al}$ and $\mathrm{Fe}-\mathrm{Cr}-\mathrm{Al}$ alloys, Corro. Sci. 48(3) (2006) 741-765.

57. R. Cueff, H. Buscail, E. Caudron, C. Issartel and F. Riffard, Oxidation behaviour of Kanthal $A 1$ and Kanthal AF at $1173 \mathrm{~K}$ : effect of yttrium alloying addition, Appl. Surf. Sci. 207(1-4) (2003) 246-254.

58. I. V. Oryshich and O. S. Kostyrko, Infleuence of molybdenum, tungsten, and cobalt on the corrosion of high-temperature strength nickel alloys in molten salts, Met. Sci. Heat Treat. 27(10) (1985) 740-746.

59. J. W. Wang, C. Z. Zhang, Z. H. Li, H. X. Zhou, J. X. He and J. C. Yu, Corrosion behavior of nickel-based superalloys in thermal storage medium of molten eutectic $\mathrm{NaCl}-\mathrm{MgCl}_{2}$ in atmosphere, Sol. Energy Mater. Sol. Cells 164 (2017) 146-155. 
60. S. Boghosian, A. Godø, H. Mediaas and T. Østvold, Oxide complexes in alkali-alkalineearth chloride melts, Acta Chem. Scand. 45 (1991) 145-157.

61. H. E. Bartlftt and K. E. Johnson, Electrolytic reduction and Ellingham diagrams for oxyanion systems, Can. J. Chem. 44(18) (1966) 2119-2129.

62. J. Engkvist, S. Canovic, K. Hellström, A. Järdnäs, J. E. Svensson, L. G. Johansson, M. O. Johansson and M. Halvarsson, Alumina scale formation on a powder metallurgical FeCrAl alloy (Kanthal APMT) at 900-1,100 $\mathrm{C}$ in dry $\mathrm{O}_{2}$ and in $\mathrm{O}_{2}+\mathrm{H}_{2} \mathrm{O}$, Oxid. Met. 73(1-2) (2010) 233-253.

63. T. Ishitsuka, and K. Nose, Stability of protective oxide films in waste incineration environment-solubility measurement of oxides in molten chlorides, Corr. Sci. 44 (2002) Jg., Nr. 2, 247-263.

64. T. J. Pan, Y. S. Li, Q. Yang, R. F. Feng and A. Hirose, Internal oxidation and phase transformations of multi-phase $\mathrm{Fe}-\mathrm{Ni}-\mathrm{Al}$ and $\mathrm{Fe}-\mathrm{Ni}-\mathrm{Al}-\mathrm{Cr}$ alloys induced by $\mathrm{KCl}$ corrosion, Corr. Sci. 53(6) (2011) 2115-2121. 